\title{
MOVENDO-SE ATRAVÉS DA DIFERENÇA: DANÇA E DEFICIÊNCIA*
}

\author{
Ann Cooper Albright** \\ Tradução e Revisão: Consuelo Vallandro Barbo*** e Mônica Fagundes Dantas*****
}

\section{Resumo}

O artigo centra-se na noção de deficiência, questionando as maneiras como a dança profissional tem sido tradicionalmente estruturada por uma mentalidade exclusivista que projeta uma visão de um bailarino como sendo branco, do sexo feminino, esbelto, de membros alongados, flexível e capaz (não deficiente). Aborda igualmente o crescente desejo de revisar radicalmente este paradigma reimaginando que tipos de movimentos podem constituir a dança e, por extensão, que tipo de corpo pode constituir um bailarino. Apesar da maior parte das discussões centralizar-se em danças específicas e nas várias respostas críticas a elas, propõe-se também a revelar as maneiras complexas pelas quais a oposição de corpos plenamente capazes e de corpos debilitados estão implicados em muitos dos paradigmas culturais dominantes de saúde e autodeterminação.

\begin{abstract}
This article focuses on the notion of disability, questioning the ways in which professional dance has traditionally been structured by an exclusionary mindset that projects a vision of a dancer as white, female, thin, long-limbed, flexible and able-bodied. It also addresses the growing desire to radically revise this paradigm reenvisioning what kinds of movements can constitute a dance and, by extension, what kind of body can constitute a dancer. Although most of the discussion is centered in specific dances and in several critical responses to them, it is also proposed to reveal the complex ways in which the opposition of fit and frail bodies is implicated within many of the dominant cultural paradigms of health and self-determination.
\end{abstract}

\footnotetext{
* Este artigo foi originalmente publicado como um capítulo intitulado Moving Across Difference: Dance and Disability, no livro Choregraphing Difference: The Body and Identity in Contemporary Dance (1997), de Ann Cooper Albright.

** Professora associada do Oberlin College.Ohio.Estados Unidos.E-mail: aalbrigh@oberlin.edu

*** Mestranda em Artes Cênicas. Universidade Federal do Rio Grande do Sul. Porto Alegre. RS. Brasil. 
Em 1838, Théophile Gautier escreveu as seguintes frases para descrever a romântica bailarina Marie Taglioni: "Mlle. Taglioni fez você lembrar vales frios e sombrios, onde surge, de repente, uma visão branca da casca de um carvalho para cumprimentar os olhos de um jovem pastor surpreso e corado; ela certamente se parecia com aquelas fadas da Escócia de quem Walter Scott fala, que vagueiam sob a luz da lua perto da fonte misteriosa, com um colar de gotas de orvalho e um fio dourado como cinta "." A descrição da dança de Taglioni feita por Gautier está focada em sua graça, delicadeza e leveza, sugerindo uma criatura sílfide, que transcende seu próprio corpo material para promover uma visão tentadoramente elusiva do desejo do espectador. A ilusão final, é claro, é de um corpo dançante perfeito - um corpo livre do suor, da dor e da evidência de qualquer negociação física com a gravidade.

Como um discurso expressivo contendo movimento físico, a dança tradicionalmente tem privilegiado o corpo não deficiente. Geralmente dançarinos são tratados com uma certa admiração paradoxal, uma estranha mistura de respeito pela disciplina física de aulas diárias de técnica, fascinação pelo que com frequência é uma graça supostamente "natural" (mas que é, obviamente, um resultado de treinamento físico intenso) e a velha e pura objetivação. Embora a "aparência" dos bailarinos tenha realmente mudado com as revoluções política, econômica, intelectual e estética da cultura ocidental nos últimos 150 anos, a imagem idealizada da bailarina clássica bem como o voyeurismo implícito no olhar fixo do apreciador de ballet ainda formam sutilmente a visão da maioria das pessoas sobre a dança profissional. Devemos perguntar 0 quão diferente é a visão contemporânea de Lock da sua musa-bailarina Louise Lecavalier como uma Joana D'Arc punk em comparação com a fantasia de Gautier vendo Taglioni como uma fada elusiva. As estruturas de representação e as molduras que cercam os corpos destas mulheres não seriam essencialmente os mesmos? No entanto, se até o corpo mais forte, visivelmente musculoso de uma bailarina pode ser facilmente comoditizado e incorporado na economia do olhar masculino, então que tipo de corpo seria necessário para quebrar este contrato visual um deficiente?

Este artigo é sobre deficiência - sobre as maneiras como a dança profissional tem sido tradicionalmente estruturada por uma mentalidade exclusivista que projeta uma visão bitoladíssima de um bailarino como sendo branco, do sexo feminino, esbelto, de membros alongados, flexível e capaz (não deficiente). Este artigo também fala sobre o crescente desejo, das várias comunidades de dança e companhias profissionais, de revisar radicalmente este paradigma reimaginando que tipos de movimentos podem constituir a dança e, por extensão, que tipo de corpo pode constituir um bailarino. Já que as categorias opostas sempre imaginam o "outro" dentro delas mesmas, este artigo viaja através do espectro de representações de beleza e grotesco, de saúde e doença, alienação e comunidade, autonomia e interdependência. Nas páginas seguintes, eu discuto sobre performances que poucas pessoas tiveram a chance de ver, bem como sobre outras danças que estão bem no centro de debates contemporâneos a respeito do papel da política e da vida na arte. Olho para corpos dançantes que vão de vigorosamente virtuosos a praticamente imóveis. Demonstrando como algumas danças recentes desconstroem a polarização de deficiência e não deficiência, vou desafiar a visão prevalecente da dança profissional que equaciona capacidade física com qualidade estética. Investigo, ainda, que tipo de olhar observador está implícito nas prioridades estéticas de diferentes grupos e examino as maneiras pelas quais um olhar tradicionalmente voyeurístico pode ser, ao mesmo tempo, fraturado e reconstruído, olhando corpos que questionam radicalmente a imagem ideal da psique de um dançarino. Apesar da maior parte da minha discussão centralizar-se em danças específicas e nas várias respostas críticas a elas, eu espero também revelar as maneiras complexas pelas quais se implica a oposição de corpos plenamente capazes e de corpos debilitados em

Publicado originalmente em La Presse, 30 de julho de 1846. Publicado novamente em GUEST (1986). 
muitos dos nossos paradigmas culturais dominantes de saúde e autodeterminação. Dado que a deficiência significa a antítese cultural do corpo saudável e em forma, o que acontece quando pessoas visivelmente deficientes assumem o papel de bailarino, aquele mesmo papel que tem sido historicamente reservado para a glorificação de um corpo ideal? A integração de corpos deficientes na dança contemporânea resulta em uma ruptura de preconceitos contra deficientes na dança profissional? Ou o corpo deficiente transcende sua deficiência para se tornar um dançarino? O que está em jogo nestas perguntas não é meramente a definição física do corpo de um bailarino, mas a estrutura mais ampla (metafísica) da dança como uma forma de representação. Quando dançarinos tomam seus lugares em frente aos holofotes, eles são frequentemente dispostos de maneira a acentuar o duplo papel de proeza técnica e desejo sexual (o último sendo implícito no próprio fato da disponibilidade visual do corpo). Em contrapartida, o corpo deficiente deve supostamente ser coberto ou escondido da vista, para ser compensado ou superado (literal ou metaforicamente) numa tentativa de viver uma vida tão normal quanto possível. Quando um dançarino deficiente entra no palco, reivindica seu direito a um espaço radical, um lugar sem regras, onde suposições disparatadas se chocam.

A interseção entre dança e deficiência é um lugar extraordinariamente rico para explorar as construções sobrepostas da habilidade física do corpo, da subjetividade e da visibilidade cultural. Buscar o significado destas construções é como fazer uma escavação arqueológica para dentro dos medos psíquicos que a deficiência cria. No seu ensaio cheio de insights The Other Body (O Outro Corpo), Ynestra King (1993) afirma: "Pessoas com deficiência visível (como as mulheres) nesta cultura são bode expiatório para os ressentimentos das limitações da vida orgânica". Para examinar tais preconceitos no mundo da dança profissional, deve-se confrontar os significados ideológicos e os simbólicos que o corpo deficiente carrega em nossa cultura, assim como as condições práticas da deficiência. Novamente, nós estamos na posição de ter que negociar entre as representações teatrais de corpos dançantes e a realidade de suas experiências físicas. Assistir a corpos deficientes dançando nos força a ver por meio de uma visão dupla, e nos ajuda a reconhecer que, mesmo que uma performance de dança seja baseada nas capacidades físicas do dançarino, ela não é limitada por elas.

Apesar de eu lutar (e basicamente me sinto desconfortável) com o adjetivo deficiente, eu passei a apreciar a palavra deficiência, que às vezes escrevo de/eficiência. Eu cunhei esta nova escrita para exagerar o precipício intelectual implícito nesta palavra. A barra ${ }^{* *}$, para mim, nega o conforto de um estereótipo. É um símbolo que marca um barranco íngreme, obrigando o leitor a dar uma parada repentina e respirar fundo pelo medo de escorregar nele. Funciona também como um espelho que reflete a face de alguém quando a sua boca tenta pronunciar o estado do outro lado do marcador. Diga: De/eficiência. Esse prefixo captura tanto, no entanto pode, eu acredito, ser criativamente reinventado. Pense, por exemplo, em todos aqueles $\mathrm{De}(\mathrm{se}) \mathrm{s}$ que são úteis em sacudir os poderes que forem - decompor, depor, decifrar, decapitar, sem falar em desarmar. Na mesma linha, a cultura popular inverteu a dinâmica do poder de "You are dismissed, young lady" (você está dispensada, jovem) para criar a expressão maravilhosamente capacitada dissed, que aparece em "I totally dissed her" (gíria para "eu a insultei por completo"). Claro que esta semântica transgressora é só parte da história. Brincar e pensar sobre as possibilidades do des em desabilidade sem reconhecer os corpos que marcam essa condição é muito fácil. Então, enquanto a palavra desabilidade rola da minha língua com um certo bebop, a palavra deficiente se entala em minha garganta. Em nossa cultura, corpos deficientes marcam tão insistentemente a fragilidade da saúde, da beleza e da autonomia que muitas pessoas experimentam uma reação física distinta quando encontram alguém com uma deficiência. Embora o des em desa-

N.T.: A autora refere-se à barra como sinal gráfico para enfatizar as possibilidades de reescrita da palavra 
bilidade obviamente reflita estereótipos negativos, eu me pergunto se ele pode ser revigorado, escolhido para nomear uma área de pesquisa que pode muito bem terminar por reorganizar a vida das pessoas. As políticas de nomeação são, obviamente, atormentadas eternamente pelas políticas de identidade. Quem dá nome a quem é uma questão difícil para a maioria dos críticos culturais que tentam ter respeito com o poder da língua. Enquanto, por exemplo, Nancy Mairs (1986) faz uso do termo cripple (aleijada) enquanto se descreve ("Aleijada me parece uma palavra limpa, direta e precisa...gosto da precisão com que descreve a minha condição"...), ela jamais o usaria para descrever outra pessoa. Em seu ensaio, ironicamente intitulado On Being a Cripple (Sobre Ser uma Aleijada), Mairs faz distinção entre vários termos que designam deficiência, deplorando a abstração e consequente falta de significado de sua generalidade.

Disabled (deficiente)... sugere qualquer incapacidade, física ou mental. E certamente não gosto de handicapped (incapacitado), o qual deixa implícito que fui deliberadamente colocada em desvantagem, por alguém que nem imagino (meu Deus não é um General Incapacitor) ... Estas palavras para mim parecem estar se distanciando de minha condição, alargando o abismo entre palavra e realidade. Mais remota ainda é o termo recentemente cunhado differently abled (diferentemente capacitado), que partilha do mesmo otimismo semântico que transformou países undeveloped (não desenvolvidos) em underdeveloped (subdesenvolvidos), e depois em menos desenvolvidos para finalmente chegar a nações em desenvolvimento. As pessoas continuaram morrendo de fome durante estas trocas. (MAIRS, 1986, p. 10)

Com sua analogia aguçada, Mairs (1986) ressalta como os termos politicamente corretos (portador de necessidades especiais, por exemplo) muito rapidamente se tornam problemáticos precisamente porque passam por cima de significantes de diferença importantes. Por serem tão gerais, eles tiram da diferença todo seu poder perturbador, lavando-a com uma variação açucarada de "todo mundo é diferente e tem necessidades", que é um modo conveniente de dizer simplesmente "nós não precisamos realmente prestar atenção nas suas questões". Como Barbara Hillyer (1993) deixa claro em um capítulo sobre língua e nomes em seu livro Feminism and Disability (Feminismo e Deficiência), estes termos genéricos rapidamente se tornam esvaziados de sentido. "Tal identificação de uma pessoa como basicamente qualquer outra bloqueia a possibilidade de uma análise política que não promova assimilação cultural" (p. 28). Paradoxalmente, ao adotar o termo aleijada, Mairs (1986) pode clamar provocativamente: "As a cripple, I swagger" (como uma aleijada, eu ando garbosa) (p. 9).

Apesar do seu romance teórico com o corpo, os críticos culturais contemporâneos têm prestado pouca atenção às questões da de/eficiência. Eu suspeito que seja em função de o corpo deficiente insistir em não ser bem embalado como uma metáfora. É difícil abstrair a deficiência, a realidade de seu status como ela é rompe o lustro teórico para confrontar quem quer que esteja escrevendo sobre ela. Apesar de o corpo ausente - o corpo como performativo e, portanto, temporário e transitório - ter seduzido frequentemente teóricos com sua efemeridade chique, poucos (se o fizeram) abordaram o corpo deficiente. Sua relutância vem de uma vontade de não tocar em um corpo que não é nem inteiramente presente e nem intrigantemente ausente, mas sim limiar, lutando em algum lugar entre as margens dos que teoricamente tem o pé firme no chão. Este é um medo primitivo; as realidades materiais da deficiência ameaçam romper não apenas representações meramente culturais ou preceitos teóricos, mas também modos de viver. King (1993) enfatiza a qualidade limiar de de/eficiência quando ela escreve: 
A própria condição de deficiência traz a vantagem de uma certa experiência vivida no corpo, uma vida inteira de oportunidades para a observação da reação ao desvio corporal. Ela desafia as categorias de doença e saúde, quebrado e inteiro. Está no meio disso. (p. 72)

Mas o feminismo deve se engajar com os assuntos de de/eficiência, pois me parece que a política corporal que serve como base para muitos pensamentos feministas contemporâneos tem muito a ver com o corpo político da de/eficiência. Da mesma forma que a mulher tem sido posicionada historicamente como corpo inteiro, suas subjetividades oprimidas com a matéria crua da vida, corpos deficientes (particularmente corpos deficientes femininos) são vistos como entidades esmagadoramente materiais, incapazes de transcender a especialidade física de suas necessidades diárias. Assim como o corpo feminino, o corpo deficiente é assustador e excessivo, sempre ameaçando escoar fora de seus containeres apropriados. Em uma cultura que trabalha tão ansiosamente para controlar as funções, desejos e limites físicos corporais, o corpo deficiente é imediatamente posicionado como anormal, simplesmente porque ele é um pouco mais bagunçado, ou porque ele demora um pouco mais e se move de maneira mais tortuosa para chegar ao seu destino. Acredito que o trabalho feminista de representação e os regimes disciplinares do corpo poderiam informar muito produtivamente e, por sua vez, revigorarem-se no envolvimento com estudos sobre de/eficiência.

É claro que, no estudo sobre deficiência, o feminismo tem que confrontar a associação simplista de deficiência com passividade. Isto foi verdade especialmente durante o nascente movimento feminista dos anos 70, quando noções essencialistas de o que vestir, o que ler (nada de pornografia, por favor), como caminhar, como fazer sexo, etc., deixaram pouco espaço ideológico para as contradições políticas envolvidas nas vidas práticas das feministas deficientes. Na introdução da sua coleção de ensaios sobre mulheres com deficiências, Michelle Fine e Adrienne Asch (1988) recontam uma anedota que é assustadora (e bem comum) na sua lógica peculiar:

Como uma acadêmica feminista disse para a coautora não deficiente deste ensaio: Por que estudar sobre mulheres com deficiência? Elas reforçam estereótipos tradicionais de mulheres que são dependentes, passivas e necessitadas. (p. 4)

Esta resposta me choca por ser tão completamente sem imaginação que na verdade justifica um olhar mais de perto. A maioria das feministas nunca pensaria nada comparável sobre muIheres pobres ou analfabetas que são marginalizadas, na nossa cultura, por deficiências sociais. Mas mulheres com deficiências físicas são prontamente vistas mais como indivíduos incapacitados do que como membros de uma classe social marginalizada. Um estudo interessante feito entre alunos da faculdade revelou a tendência sexista nesta questão. A maioria deles atribuiu a deficiência em homens a acidentes, incidentes de trabalho, ou guerra (não é culpa deles, é só azar), enquanto a deficiência em mulheres foi atribuída mais a causas internas, como doenças, revelando uma suposição sexista de que a deficiência em mulheres é resultado de suas próprias fraquezas ou falhas. 
Um outro assunto que feminismo e deficiência têm em comum é a desconstrução de noções existentes de self e autonomia. Os princípios fundamentais de política, filosofia e psicologia da cultura ocidental são baseados nas teorias de subjetividade individual e soberania estatal que são afirmadas em ideais simplistas de independência e autossuficiência. Até mesmo no final do século XX, com suas redes interdependentes de informação e capital global, nós ainda acreditamos que o primeiro momento de individualidade é quando a criança (ou jovem adulto) se torna independente de seus pais ou responsáveis. Esta construção do self como um indivíduo autônomo sempre foi problemática para mulheres e homens que estão envolvidos em várias linhas de interdependência, mas isso ocorre particularmente com pessoas que necessitam de assistência médica diária em suas vidas.

Com a ajuda de publicações de muitas feministas de cor e de mulheres de países em desenvolvimento, onde as famílias grandes e interligadas e a interdependência comunitária não estão completamente corroídas, o pensamento feminista contemporâneo finalmente começou a desconstruir esta visão bitolada de que a verdadeira individualidade é sinônimo de independência dos outros. Mas devem se analisar, ainda, as várias maneiras com que a nossa sociedade funde subjetividade e mobilidade física. A cultura americana foi fundada com base em uma equação simplista de individualidade com liberdade e mobilidade física (a mentalidade de fronteira ${ }^{* * *}$ ), e eu acredito que muitos deslocamentos físicos e geográficos da vida contemporânea podem ser rastreados nesta noção profundamente incrustada. A dança moderna americana em seu início partilhou com os primeiros feministas um interesse pela reforma do vestuário. Isadora Duncan, por exemplo, defendeu a crença de que liberdade intelectual e social, sem mencionar a psicológica, eram muito relacionadas à mobilidade física - neste caso, a liberação das restrições elaboradas da vestimenta vitoriana. Ao mesmo tempo em que eu concordo absolutamente que a libertação das restrições físicas da moda foi e é importante para as mulheres, acho que devemos desenvolver uma discussão mais complexa e autocrítica da liberdade física, a fim de reconhecer que a capacidade de se mover - a qualquer hora, para qualquer lugar - não se iguala necessariamente a uma verdadeira liberdade psíquica.

A degradação do corpo humano ante o seu tempo natural é trágica. Ela força o indivíduo a quem ela ocorre a passar uma dificuldade terrível. Mas a camada externa de opressão sobre o deficiente está intimamente ligada ao medo da morte e ao reconhecimento de nossa incrustação na natureza orgânica. Somos criaturas finitas, contingentes, dependentes pela nossa própria natureza; todos vamos morrer no final. Vamos todos experimentar degradações em nossa integridade física. A aspiração à integridade humana é um idealismo opressor (KING, 1993, p. 75).

Minhas experiências pessoais com dança e deficiência fizeram com que me desse conta do quanto a identidade de cada um é lida através de seu corpo e também me deram a consciência de como é realmente simplista a nossa definição cultural de de/eficiência como incapacidade física. Muitos anos atrás, eu estava temporária, mas seriamente, deficiente/incapaz quando duas discopatias assolaram minha coluna. Não só tive dificuldades em suportar a dor incessante, a exaustão, a dificuldade de me locomover, mas também achei que a equipe da área médica que estava me tratando não tinha nenhuma ideia de quem eu era e do que eu poderia continuar fazendo. Eles presumiam que, por eu estar utilizando uma cadeira de rodas ou uma bengala, já era tempo de eu pensar em me aposentar da dança (na maturidade dos 34!). Apesar de a minha deficiência ter colorido minha experiência diária por um bom tempo, ela nunca definiu inteiramente quem eu era - embora a maioria das pessoas que me conheceram naquela épo*** A mentalidade de fronteira (frontier mentality) tem a ver com a lógica de controle absoluto das terras sem lei que deveriam supostamente ser civilizadas e exploradas pelos colonizadores, que enriqueceram desenfreada- 
ca achassem difícil aceitar que eu ainda me apresentava como bailarina. Um ano mais tarde, quando estava ajudando em um workshop sobre movimento na conferência This ability ${ }^{* * *}$, fui surpreendida (mais uma vez) pelo modo simplista como fomos treinados a ler a identidade cultural através do corpo físico. Quando pedi a um grupo de participantes deficientes e não deficientes para falarem sobre as experiências de seus corpos, ficou claro que qualquer dicotomia deficiente/não-deficiente embasada na habilidade física se esvaiu. Um bom número de participantes que parecia não deficiente falou sobre suas experiências com problemas de imagem corporal (incluindo anorexia e bulimia), assim como abuso sexual e físico, as quais são fortes formadoras de deficiência. Ao mesmo tempo, algumas pessoas com limitações físicas falaram de confiança e amor a seu corpo do jeito que ele era. Apesar de uma experiência com paralisia ser mais difícil de negociar em termos de acesso, não é necessariamente mais enfraquecedora em termos pessoais do que a experiência de um distúrbio de imagem corporal, mesmo que apenas o primeiro destes casos seja considerado "deficiência" na nossa sociedade.

Assuntos sobre a deficiência afetam a vida de todo mundo. Apesar de muitos de nós estarmos familiarizados com o trabalho de escritores, músicos e artistas deficientes, são os bailarinos fisicamente deficientes que ainda são vistos como uma contradição. É porque a dança, diferentemente de outras formas de produção cultural como livros ou pintura, torna o corpo visível dentro da representação em si. Portanto, quando assistimos a uma dança com bailarinos deficientes, estamos olhando para ambas: coreografia e deficiência. Essa inserção de corpos com limitações físicas reais pode ser extremamente desconcertante para os críticos e membros da plateia que estão comprometidos com a estética de uma beleza ideal. Quebrando a imagem de porcelana de uma dançarina como uma sílfide, os bailarinos deficientes obrigam o espectador a confrontar-se com a oposição cultural corpo clássico - corpo grotesco. Em um outro texto (Albright, 1997), eu discuti sobre como a lógica binária, tão prevalecente nos nossos discursos sobre corpos, saúde, forma física, joga os corpos em forma contra os frágeis. No contexto deste artigo, esse binário é revisto como uma oposição dos corpos clássico e grotesco. Estou usando o termo grotesco da maneira que Bakhtin o evoca em sua análise da representação em Rabelais. Em sua discussão sobre carnaval, espetáculo e a teoria bakhtiniana, Mary Russo (1986) identifica estes dois trocadilhos corporais da seguinte maneira: o corpo grotesco é o aberto, o salientado, estendido, segredado, o corpo do tornar-se, do processo e da mudança. "O corpo grotesco é oposto ao corpo clássico, que é monumental, estático, fechado e suave, correspondendo às aspirações do individualismo burguês; o corpo grotesco está conectado com o resto do mundo" (RUSSO, 1986, p. 219). Eu sei que, ao usar o termo grotesco num capítulo sobre de/eficiência, eu me arrisco a invocar velhos estereótipos de corpos deficientes como sendo corpos grotescos. Esta certamente não é a minha intenção. Quando eu discuto a oposição dos corpos clássico e grotesco, não é para descrever corpos específicos, mas sim para invocar construtos culturais que influenciam profundamente nossas atitudes em relação ao corpo. Como já mencionei antes na discussão sobre nomes e terminologia, normalizar um corpo deficiente não quebra estas dicotomias de diferença social, apenas as disfarça com um discurso alternativo.

Neste texto, eu gostaria de explorar a natureza transgressiva do corpo grotesco para conferir como e se o corpo deficiente poderia desconstruir e reformar radicalmente as estruturas representacionais das performances de dança. Mas, como nenhuma deficiência é igual, coreografias com dançarinos deficientes não são completamente parecidas. Muitos destes dançarinos recriam as molduras representacionais das performances de palco tradicionais, enfatizando os elementos de virtuosidade e conhecimento técnico para reafirmar um corpo clássico apesar de suas limitações. Em contraste, algumas coreografias, em especial aquelas influenciadas pelo

A conferência, realizada em maio de 1995, na Universidade de Michigan, chamava-se Thisability, an Interdisciplinary Conference on Disability and the Arts. 
Contact Improvisation, trabalham para acabar com as próprias distinções entre o corpo clássico e o grotesco, reestruturando radicalmente as molduras de representação da dança para oferecer uma outra maneira de ver os corpos dançantes. Como podemos ver, enquanto toda dança criada sobre corpos deficientes deve negociar as contradições palpáveis entre os discursos de corpos ideais e de corpos anormais, cada obra peça vence este desafio de uma maneira diferente, estabelecendo suas próprias preocupações estéticas dentro do estilo de coreografia e movimento, assim como dentro do contexto geral da performance em si.

No início de Gypsy, o elegante e alto Todd Goodman entra puxando as pontas de uma longa echarpe enrolada nos ombros de sua parceira Mary Verdi-Fletcher, que vem deslizando atrás dele. Ao som de Gypsy Kings, ele enrosca esta echarpe ao redor dela de um lado para o outro. Os ombros nus dela tremem com o êxtase da performance. Ela joga sua cabeça para trás com um abandono de quem confia, à medida que ele inclina a parceira completamente para trás. Segurando o tecido, ela desliza como uma patinadora, alternadamente soltando e retomando controle. No clímax, ele a joga de volta para a cadeira e a faz rodopiar. Eu mencionei que Verdi-Fletcher dança em sua cadeira de rodas? (SOLOMONS, 1992)

Esta é a descrição feita por Gus Solomons (1992) de um dueto romântico que foi um dos primeiros empreendimentos coreográficos do Cleveland Ballet Dancing Wheels, uma companhia profissional de dança constituída por dançarinos sobre pernas e dançarinos em cadeiras de rodas. Essencialmente um pas de deux para pernas e rodas, Gypsy expande a herança estética do balé romântico do século XIX em diversas direções novas e interessantes. Como um dueto de balé tradicional, Gypsy é construído em cima de uma ilusão de graça, provida pelos movimentos fluidos e pela física de parceria. $O$ uso do tecido juntamente com a cadeira de rodas dá ao movimento uma qualidade contínua que é difícil de conseguir 'sobre pernas'. Quando Solomons (1992) descreve a dança de Verdi-Fletcher como deslizante, ele está não só usando uma metáfora, mas transcrevendo a realidade física do movimento dela. Tocando-se de fato fisicamente ou estando conectados pelo seu cordão umbilical de seda, neste pas de deux, os dançarinos fazem uma parceria recíproca com uma combinação da delicadeza do balé com o mistério do tango.

Solomons é um crítico de dança afro-americana e um coreógrafo independente que tem se envolvido na cena da dança contemporânea desde os tempos em que ele dançava para Merce Cunningham nos anos 1970. Membro ativo da Associação de Críticos de Dança, ele tem falado eloquentemente sobre a necessidade de incluir comunidades diversas em nossas definições de dança atual. Contudo, como muitos outros críticos culturais liberais e comentaristas de arte, Solomons (1992) estabelece uma retórica peculiar na passagem acima, a qual tenta negar a diferença. Sua observação: "Eu mencionei que Verdi-Fletcher dança em sua cadeira de rodas?" sugere que a presença de uma bailarina em uma cadeira de rodas é meramente um detalhe eventual que mal interrompe o fluir perfeito do pas de deux romântico. Ao assumir que a deficiência não faz uma (grande) diferença, este autor está, na verdade, limitando a diferença (real) que a de/eficiência pode fazer ao reformular radicalmente como olhamos, concebemos e organizamos corpos no século XXI. Por que, por exemplo, Solomons (1992) inicia com uma descrição do corpo não deficiente de Goodman como sendo "alto e elegante" e então peca em não descrever nada do de Verdi-Fletcher? Por que a maioria dos artigos da companhia de dança seminal de Verdi-Fletcher gasta tanto tempo celebrando como ela superou sua deficiência para 
se tornar uma bailarina em vez de indagar como sua presença corporal pode reformular radicalmente a própria categoria de bailarinos?

As respostas a estas perguntas não estão apenas em um exame da recepção crítica de Gypsy e outros empreendimentos coreográficos do Cleveland Ballet Dancing Wheels, mas também em uma análise da maneira pela qual esta companhia paradoxalmente reconhece e depois esconde a diferença que a de/eficiência faz. A seguir, vou esmiuçar as contradições encravadas nas prioridades estéticas e sociais tão diferentes desta companhia; enquanto o seu trabalho mundo afora tem aberto campo de trabalho importante para a inclusão estrutural de pessoas com deficiência nos programas de treinamento de dança e locais de apresentação, a estética conservadora que guia o trabalho do Cleveland Ballet Dancing Wheels paradoxalmente reforça, mais do que interrompe, as conotações negativas da deficiência.

A Dancing Wheels iniciou como uma aventura conjunta entre Mary Verdi-Fletcher, que nasceu com uma espinha bífida e agora usa uma cadeira de rodas, e David Brewster, o marido de uma amiga que gostava de dança de salão tanto quanto Mary. Nos inebriantes dias da disco fever, eles competiram em vários concursos de dança de salão. Mas logo se concretizou a ideia de ter uma companhia de dança com deficientes e não deficientes. Em 1980, Verdi-Fletcher fundou a Dancing Wheels e começou a se concentrar na expansão e na formação de público, fazendo palestras-demonstrações em centros comunitários e apresentações em escolas e lares de idosos. Em 1990, Verdi-Fletcher e seu (então) diretor adjunto Todd Goodman (que dança sobre pernas) se juntaram ao Cleveland Ballet para formar a atual companhia Cleveland Ballet Dancing Wheels. Hoje em dia, a Dancing Wheels não atua mais nas temporadas regulares do Cleveland Ballet - as suas contribuições mais importantes são para o programa educacional e de expansão do Cleveland Ballet. De uma maneira independente, a companhia faz parcerias com vários coreógrafos de ballet clássico e moderno, apresentando seus trabalhos em vários locais pelo país.

O início da companhia foi pitorescamente relatado pelo diretor artístico do Cleveland Ballet, Dennis Nathan. Ele lembrou ter encontrado Verdi-Fletcher em uma recepção quando ela se apresentou como bailarina e lhe contou da vontade de dançar para o Cleveland Ballet. Na biografia comentada da carreira de Verdi-Fletcher na dança, escrita para a festa de gala do 150 aniversário da Dancing Wheels, Nathan é citado ao dizer: "Quando eu vi Mary atuando pela primeira vez, eu disse 'Que bailarina ${ }^{* * * *}$.' ...Sem nenhuma chance de estar errado a respeito disso. Ela tinha a chama, o espírito que faz um bailarino" . Estou interessada em seguir um pouco com essa noção de espírito, especialmente porque ela é usada com frequência dentro do próprio material impresso da companhia. Por exemplo, em um material elaborado para um evento da mídia, feito para comemorar a parceria com a Action Technology da Invacare Corporation (linha de cadeiras de roda com manuseio mais fácil e maior mobilidade), existe uma foto da companhia com a frase "Uma Vitória do Espírito sobre o Corpo" na legenda.

Eu considero bem problemática esta noção do espírito dançante que transcende as limitações de um corpo deficiente. Apesar de, inicialmente, parecer uma linguagem libertadora - a pessoa não deve ser confinada por definições sociais de identidade baseadas nos atributos corporais (ou em raça, gênero, condição física, etc.) -, esta retórica é, na verdade, baseada na noção preconceituosa da superação de deficiências físicas (a teoria do super-deficiente) para se tornar um bailarino de verdade, cujo espírito não deixa as limitações de seu corpo o atrapalharem. Considerando que os corpos dos bailarinos estão geralmente expostos em uma apresentação, esse compromisso com o espírito acima do corpo arrisca esconder ou apagar os corpos deficientes integralmente. Como podemos representar o espírito - rostos sorridentes, alegres elevações no 
ar? Na mesma página, a fotografia de publicidade da companhia nos dá um exemplo do menosprezo visual dos corpos com deficiência. Nesta foto de estúdio, os três bailarinos em cadeiras de rodas estão artisticamente rodeados por corpos de bailarinos não deficientes de tal maneira que mal podemos ver as cadeiras; na verdade, Verdi-Fletcher está erguida e ladeada por quatro homens bem próximos a ela, de modo que parece que ela está na terceira fileira. Mas o que chama mais atenção nesta fotografia publicitária é a maneira como a bailarina sentada à direita tem suas longas e esbeltas pernas estendidas ao longo do pé da foto. $O$ efeito, de forma bastante estranha, é fazer destas pernas sadias um fetiche e, ao mesmo tempo, tornar a outra mobilidade - as rodas - invisível. Não estou dizendo que esta foto foi deliberadamente montada para minimizar a representação visual da deficiência. Porém, este exemplo nos mostra que, a não ser que construamos conscientemente novas imagens e maneiras de imaginar o corpo deficiente, inevitavelmente vamos reproduzir uma estética preconceituosa. Apesar de o texto clamar com júbilo sua identidade, Greetings from Cleveland Ballet Dancing Wheels, a foto normaliza a diferença entre os corpos, tranquilizando os potenciais apresentadores e a imprensa de que eles não vão assistir a nada muito desconfortável.

A primeira frase da missão do Cleveland Ballet Dancing Wheels assevera que a companhia trabalha para "promover a parceria e os talentos artísticos de bailarinos com e sem deficiência demonstrando a diversidade da dança e as habilidades dos artistas portadores de deficiência ${ }^{* * * * * * \prime}$. Esta é uma missão verdadeiramente importante. Com seus extensos programas educacionais e de expansão, que incluem dar aulas de dança para bailarinos com deficiência e palestras-demonstrações em escolas locais e centros comunitários, assim como com suas apresentações, a Dancing Wheels aumentou a visibilidade de bailarinos com corpos diferentes. Mary Verdi-Fletcher é um modelo poderoso para jovens dançarinos cadeirantes. Em um artigo que documenta o quanto o trabalho de Verdi-Fletcher tem sido inspiração para jovens meninas tornarem realidade seus sonhos de dançar, Steve Wright (1993) relata que "Melissa Holbrood e algumas centenas de colegas seus da escola fundamental Brown aprenderam ontem que você não precisa de suas pernas para dançar e que usuárias de cadeiras de rodas podem ser bailarinas". A curta matéria termina citando Verdi-Fletcher ao observar que "seus parceiros de dança descobriram que é muito mais fácil arrastar uma mulher de rodas do que uma de salto alto" (WRIGHT, 1993). Eu admiro este papel maravilhoso e exemplar de embaixadora cultural no qual Verdi-Fletcher está realmente se sobressaindo, porém estou curiosa sobre a postura aparentemente acrítica que ela e a companhia parecem ter sobre as representações de mulheres e imagens de de/eficiência. O Cleveland Ballet Dancing Wheels certamente fez aumentar a visibilidade de bailarinos com diferentes deficiências - mas devemos perguntar: visíveis de que maneira, e às custas de quem? Enquanto a base representacional para seu trabalho está mais imersa nos valores ideológicos da dança clássica e da estética formalista (completa com a transformação da linha em fetiche), suas tentativas de incluir bailarinos sobre rodas podem ser recolocadas rapidamente nos mesmos velhos termos padronizadores de corpos deficientes e não deficientes ${ }^{* * * * * *}$.

Flashback (1992) é uma parceria coreográfica da Tom Evert Dance e da Dancing Wheels e tem sido apresentada em Ohio e no Marymount Manhattan Theater em Nova lorque. Este espetáculo é composto de uma série de vinhetas curtas compondo uma narrativa livre, que percorre

\footnotetext{
******* Material de divulgação do Cleveland Ballet Dancing Wheels, 1993

******* Em uma conversa por telefone (janeiro de 1997), Mary Verdi-Flechter expressou sua preocupação em relação ao fato de que minha análise do Cleveland Ballet Dancing Wheels baseava-se em seus trabalhos mais antigos, bastante diferentes do repertório atual da Companhia. Eu tentei manter-me atualizada em relação às mudanças do trabalho da Companhia e nas próximas discussóes comparo danças criadas entre 1992 a 1995 . Meu objetivo não é categorizar todas as produções da companhia, mas sim utilizar trabalhos específicos a fim de articular os temas em questão nas representações de de/eficiência.
} 
um caminho de volta no tempo partindo do amor adulto na primeira cena até chegar à última, que representa uma brincadeira infantil. O estilo de dança é um cruzamento entre a técnica clássica e o teatro naturalista, e cada cena é dançada por bailarinos tanto sobre pernas como também sobre cadeiras de rodas. Entretanto, Mary Verdi-Fletcher é a única bailarina em cadeira de rodas que é realmente deficiente - os outros fazem o papel por conta do enredo. Apesar de este espetáculo ter sido feito para passar a mensagem de que os artistas deficientes podem se integrar na dança profissional, uma análise estrutural do movimento revela que cada cena, na verdade, reescreve o de da palavra deficiente, marcando a falta de pernas com mobilidade em vez de explorar as possibilidades de movimento inerentes aos vários tipos de corpos.

No início do espetáculo, os bailarinos se apresentam ao público movendo-se em uníssono pelo palco. Os três dançarinos sobre pernas andam em ziguezague entre os dançarinos com cadeiras de roda, dando uma mão aqui, outra lá, para balançar seu parceiro em um semicírculo no chão. Entretanto, o relacionamento físico logo fica desigual: os dançarinos sobre pernas direcionam e motivam o movimento das cadeiras, e aqueles sobre rodas seguem, mas nunca iniciam de fato qualquer movimento. Os bailarinos sobre rodas fazem uma série de gestos de fundamento clássico com os braços juntamente com os dançarinos sobre pernas, que geralmente estendem o movimento para seus dorsos em um arabesque. Com frequência os dançarinos sobre rodas são usados como dispositivos arquiteturais estáticos para enquadrar aqueles sobre pernas, que estão ocupados apresentando a verdadeira dança de corpo inteiro no centro do palco.

Dois duetos seguem esta cena. O primeiro é uma valsa romântica - estilo cadeira de rodas. Esta cena tem um dos usos mais criativos de coreografia com cadeira de rodas, pois não há bailarinos 'sobre pernas' para guiar as cadeiras pelo espaço. Um bom exemplo ocorre quando dois dançarinos em rodas, Verdi-Fletcher e Nick Carlisle, se aproximam um do outro com tal energia de movimento que se balançam em um círculo. Entretanto, a significância da coreografia deste dueto é rapidamente cortada quando dois bailarinos sobre pernas, Todd Goodman e Susanna Weingarten da Evert, entram no palco para apresentar seu dueto - um tango latino, repleto com olhares sedutores, um vestido curto, uma parceria física íntimos. A implicação é clara: dançarinos sobre rodas podem ser docemente românticos, mas a dança sexy e excitante está reservada para aqueles com pernas.

A próxima cena começa com uma transição melodramática em que o dançarino sobre rodas levanta da sua cadeira como um fantasma e sai do palco enquanto outro bailarino toma seu lugar. De repente, o tempo e o lugar mudaram, e nós vemos um inválido e sua enfermeira animada saltitando pelo palco. Esta cena em particular me choca por ser um dos momentos mais ideologicamente peculiares do espetáculo, pois ela parece invocar todos os piores estereótipos de deficiência de uma maneira completamente acrítica. O homem na cadeira de rodas agora é claramente a vítima de algum acidente. A figura da enfermeira o trata como uma criança, limpando sua boca e empurrando-o alegremente pelo palco. Por vezes ela corre na frente, batendo palmas quando ele a segue. Tipicamente, é ela quem dirige todos os movimentos de ação; é ela que toca nele, senta no colo dele de uma maneira provocante e ainda o adverte com um tapa quando ele tenta tocá-la como resposta.

Flashback foi o início da parceria do Cleveland Ballet Dancing Wheels com muitos coreógrafos. No verão de 1992, a Dancing Wheels promoveu um workshop coreográfico para estimular os coreógrafos de Ohio a criar trabalhos para um grupo misto de bailarinos com e sem deficiência. O evento de uma semana de duração culminou numa mostra de trabalho em andamento. Este foi o começo de uma série de workshops que até hoje tem influenciado muito por mostrar 
a coreógrafos locais as possibilidades de movimento em cadeiras de roda (ULE-GROHOL, 1995, p. 61). Então, em 1994, o coreógrafo da casa Todd Goodman (cuja estética estava firmemente embasada no mundo do balé e do teatro musical) partiu. Ele foi substituído por Sabatino Verlezza, um coreógrafo de Nova lorque que trabalhou com a companhia durante a Celebration of Arts and Access em 1993 (ULE-GROHOL, 1995, p. 74).

O conhecimento anterior de Verlezza sobre dança moderna trouxe uma mudança muito bem-vinda ao vocabulário físico da Dancing Wheels. Em agosto de 1995, o Cleveland Ballet Dancing Wheels fez uma apresentação de gala beneficente no Cleveland Playhouse State Theater. O programa abriu com uma reconstrução de uma coreografia criada por Mary O'Donnell em 1959, com quem Verlezza dançou por muitos anos. Originalmente parte da companhia de dança Marta Graham, O'Donnell tem desenvolvido um estilo coreográfico mais alusivo a Doris Humphrey, ao início da dança moderna, com um estilo de movimento mais coletivo e expressivo. Em seu uso do espaço, queda e recuperação, além de ritmos de respiração, Dance Energies remeteu ao grande épico moderno de Humphrey, New Dance.

Apesar de Verlezza frequentemente em suas obras coreografar um tema central para dançarinos com pernas, deixando para os dançarinos sobre rodas o papel de suprir o pano de fundo arquitetural (um processo que vai contra os princípios democráticos do estatuto da companhia), ele começou a experimentar muito mais os movimentos para os dançarinos das cadeiras. Enquanto a maioria das coreografias anteriores da Dancing Wheels envolviam dançarinos sobre pernas liderando ou balançando os dançarinos sobre rodas pelo palco, no repertório atual há pelo menos algum esforço para explorar o momentum e outras possibilidades únicas para cadeiras de roda. A estreia de $1420 \mathrm{MHZ}$ ofereceu uma ótima oportunidade de ver um dos trabalhos mais desafiadores em termos físicos e conhecer movimentos extraordinários que podem ser feitos sobre rodas. $O$ fato de a peça ter sido feita para três mulheres sobre rodas permitiu que a plateia experimentasse uma verdadeira representação de capacitação da diferença, sem as comparações físicas inevitáveis que ocorrem quando mulheres sobre rodas dançam com homens sobre pernas.

Uma outra peça de Verlezza intitulada May Ring completou o programa da noite. Eu fiquei totalmente atordoada com a imagem final desta coreografia e acho difícil de acreditar que nem Verdi-Fletcher nem Verlezza estivessem cientes de como esta imagem poderia afetar algum membro de sua plateia. May Ring termina com um fade longo quando Verlezza ergue Verdi-Fletcher da cadeira, de braços completamente abertos e rosto irradiante, para acima da cabeça dele. Este final, claramente, é para ser um momento transcendental. No entanto, suas implicações inevitavelmente sexistas e preconceituosas contra deficientes - reforçadas pelo fato de que Verlezza dança sobre pernas e Verdi-Fletcher sobre rodas - me desapontaram profundamente. Como as narrativas de Disney e as canções populares da minha juventude que prometiam a salvação através do amor - esta imagem retrata Verlezza como um príncipe encantado, tomando Verdi-Fletcher para fora de sua cadeira para fazer dela uma verdadeira mulher. Mas é possível argumentar que esta imagem esteja na verdade desconstruindo o papel da bailarina clássica, uma maneira de piscar para a plateia para dizer: sim, uma mulher deficiente também pode preencher esta imagem popular. Mas o resto do trabalho não sustenta esta interpretação. A presença de uma Verdi-Fletcher sorridente e infantil sugere pouca agência por parte dela.

Em seu ensaio The Other Body, King (1993) descreve uma mulher deficiente a qual ela observa todos os dias a caminho de seu trabalho. 
Ela mal pode se mover. Ela tem um rosto bonito, pernas pequenas que não the possibilitariam caminhar sobre elas. Mas ela veste meias de renda pretas e salto bem alto e pontudo ... O fato de ela poder 'exibir' seu ser sexual viola o código de aparência aceitável para mulheres deficientes (KING, 1993, p. 74).

O que chama a atenção de King (1993) sobre a aparição bem-vestida desta mulher é a maneira pela qual ela ao mesmo tempo nega a sua posição cultural como um ser assexuado e desconstrói os ícones de sexualidade feminina (afinal, quem é que pode caminhar naqueles sapatos de salto?). Assistindo a Verdi-Fletcher nos momentos finais de May Ring, a gente se depara com as contradições de ser colocada tanto como uma bailarina clássica (ao mesmo tempo sexualizada e objetificada) e uma mulher deficiente (uma criança assexuada que necessita de ajuda). Ao invés de uma posição trazer tensão para a outra ou quebrá-la (como o exemplo de King da mulher deficiente com salto alto e meia de renda preta), Verdi-Fletcher parece aqui estar adotando uma posição que é duplamente enfraquecedora.

Desde este espetáculo, tenho buscado as razões pelas quais ela teria permitido uma apresentação em tais moldes, já que estamos em meio a uma enorme campanha publicitária que procura representar Verdi-Fletcher como uma mulher extraordinária que superou as dificuldades da espinha bífida para realizar o seu sonho de ser uma bailarina profissional. Em retrospecto, eu acho que este desejo de se colocar no foco das atenções tem tudo a ver com a imagem poderosamente sedutora da bailarina clássica romântica como uma sílfide inatingível. Parece-me que, quando Verdi-Fletcher fecha seus olhos e sonha em se tornar uma bailarina, ela ainda está visando uma fada açucarada do Quebra-Nozes. Embora tenha aberto com muito sucesso o campo da dança profissional sobre rodas, Verdi-Fletcher ainda não desafiou o mito da sílfide. Apesar de suas recentes incursões na dança moderna, a Dancing Wheels ainda parece presa à ideologia clássica do corpo perfeito.

Mary Verdi-Fletcher é uma bailarina e, como muitas outras bailarinas, deficientes ou não, ela internalizou uma estética de beleza, graça e linha que, se não é centrada em um corpo completamente móvel, é, no entanto, comprometida com uma imagem corporal idealizada. Há muito poucas profissões em que o esforço para manter o corpo perfeito (ou pelo menos quase perfeito) tenha envolvido tanta luta física e psíquica como no campo da dança. Com poucas exceções, esta é a verdade seja a técnica preferida o balé clássico, a dança americana moderna, a Bharatanatyam ou uma forma de dança afro-americana. Apesar de o estilo e aparência dos corpos favorecidos por diferentes culturas de dança poderem permitir algum grau de variação, a maior parte da dança profissional ainda está inundada por questões de imagem corporal e controle de peso (por exemplo, a diretora do Urban Bush Women, Jawole Willa Jo Zollar, fala sobre a liberdade de ter e de mover a sua própria bunda em danças africanas como sendo maravilhosamente libertadora após anos de ordens de segurá-la em aulas de dança moderna). Até mesmo companhias como a Bill T. Jones e Arnie Zane Dance Company, que se orgulham da diversidade de seus bailarinos, raramente têm muita variação entre as bailarinas (que são todas muito magras). Toda vez que um corpo de bailarino não for completamente esbelto, a imprensa faz uma observação. De fato, o discurso sobre controle de peso e dieta dentro da classe está tão difundido (principal, mas não exclusivamente para mulheres) que nós nem o percebemos mais. Eu fico constantemente espantada com bailarinas que conscientemente desconstruíram as ima- 
gens tradicionais de dançarinas no seu trabalho coreográfico e, no entanto, se queixam de seu excesso de peso, rugas, cabelo branco ou qualquer coisa caída. Como um corpo em exposição, o bailarino está sujeito ao olhar fiscalizador do coreógrafo e do público, mas nenhum destes olhares é mais debilitador e opressor do que o olhar que encontra sua própria imagem refletida no espelho.

Nos últimos 20 anos, tem se escrito muito sobre as maneiras pelas quais a dança gera uma atmosfera insalubre de dietas, exercícios e intenso uso de drogas para obter e manter um corpo artificialmente magro. Isto é verdade principalmente em escolas e companhias de balé clássico. O mais influente livro do Dr. L. M. Vincent, Competing with the Sylph: Dancers and the Pursuit of the Ideal Body Form (1979) (Competindo com a sílfide: bailarinos e a busca da forma ideal de corpo) é cheio de relatos orais de dietas extremas e jejuns que as meninas fazem para atrasar as mudanças fisiológicas pelas quais seus corpos estão passando. Apesar de menos visíveis que as deficiências de mobilidade, os problemas de imagem corporal e os distúrbios de alimentação resultantes constituem uma das maiores questões de de/eficiência na dança. Livros como Off Balance: The Real World Of Ballet, de Suzanne Gordon (1986), Women and Dance, de Christy Adair (1992), e relatos autobiográficos como o de Gelsey Kirkland (1986), estrela do New York City Ballet (uma estória bem medonha sobre adição e ódio próprio) documentam toda a gama de horrores a que meninas e mulheres se submetem para perseguir o corpo ideal para a dança. As formas de dança contemporâneas e modernas, assim como as tradicionais de outras culturas, podem ter deixado um pouco a tirania da magreza, porém elas a substituíram, em geral, por uma nova expectativa, a de corpos visivelmente musculosos. Na verdade, é raro o bailarino profissional hoje que não tem um bíceps bem torneado.

Da mesma forma que a sociedade cria um ideal de beleza que oprime a todos nós, ela cria um modelo ideal da pessoa fisicamente perfeita que não é assediada pela fraqueza, perda, ou dor, ... A mulher deficiente (e a de idade avançada) gera uma ameaça simbólica ao lembrar-nos da tenuidade que este modelo, 'o mito do corpo perfeito', tem..." (GALLER, 1984, p. 166)

Em seu ensaio The Myth Of The Perfect Body (O mito do Corpo Perfeito), Roberta Galler (1984) sugere que mulheres deficientes usem a "ameaça simbólica" que seus corpos criam contra as ideologias dominantes de beleza, saúde e feminilidade para quebrar estes ideais opressores. Galler escreve (1984) que

(...) mulheres deficientes (e de idade avançada) estão aparecendo; nós estamos começando a examinar nossas questões publicamente, obrigando outras mulheres a não apenas tratar de questões de deficiência, mas também reexaminar suas atitudes perante suas próprias limitações e falta de perfeição perante mitos, padrões e condições sociais opressores que afetam a todos. (p. 167)

Nestas aparições, incluem-se ações como fazer parte de grupos populares em escolas, participar de conferências, engajar-se em atos políticos e escrever. Recentemente eu li uma obra de 
uma das mais persuasivas ensaístas contemporâneas, Nancy Mairs, cujos escritos autobiográficos documentam as complexidades de viver com uma doença degenerativa (esclerose múltipla) e a dupla força que lhe cresce: de seu amor próprio e da consciência da sua identidade como escritora no meio de uma perda gradual do controle neurológico. Ao articular sua vida, Mairs (1996) também articula as negociações que ocorrem entre suas experiências físicas e a completa falta de representação pública delas ${ }^{* * * * * * *}$. Por exemplo, uma vez Mairs perguntou a um agente publicitário a razão de ele nunca usar pessoas deficientes em seus comerciais de detergente e cereais. Ele respondeu que ninguém queria dar ao público a ideia de que estes produtos são apenas para deficientes. Mairs (1996) conclui que essa resposta

(...) mascara um raciocínio mais ansioso e profundo: mostrar pessoas deficientes nas atividades normais do dia a dia é admitir que existe algo de corriqueiro na própria deficiência, e que ela pode aparecer na vida de qualquer um. (p. 33)

De fato, a deficiência está finalmente começando a entrar na consciência do público. $O$ Americans with Disabilities Act - ADA - (Ato dos Americanos com Deficiência), de 1990, obriga, cada vez mais, as instituições a tornar seus espaços acessíveis ${ }^{* * * * * * *}$. Ironicamente, ao mesmo tempo em que o movimento de vida independente ganha momentum e as pessoas deficientes se tornam (de alguma maneira) mais visíveis, a cultura americana está enfatizando, com uma paixão até agora não imaginável, a necessidade de controle físico e corporal ${ }^{* * * * * * *}$. Como King (1993) salienta em seu ensaio The Other Body, este fetiche do controle marca o corpo deficiente como uma antítese social - um corpo fora de controle:

Não é mais suficiente ser magro; devemos ter definição muscular ubíqua, nada solto, flácido, ou pouco definido, nenhum limite confuso. E, é claro, há a importância do controle. Controle sobre o envelhecimento, processos corporais, peso, fertilidade, tônus muscular, qualidade da pele e movimento. Mulheres deficientes, independentemente do quão magras, não têm total controle corporal. (p. 74)

Eu estou convencida de que esta questão do controle seja a chave para compreender não apenas as questões específicas do preconceito contra os deficientes, mas também o espaço simbólico maior que a deficiência ocupa na imaginação psicológica da nossa cultura. Na dança, este contraste entre os corpos clássico e grotesco é frequentemente enquadrado em termos de controle físico e virtuosidade técnica. Apesar de o corpo dançante estar se movendo e, neste sentido, estar sempre em fluxo e mudando a todo momento, o estilo de movimento ou coreografia pode enfatizar imagens ressonantes do corpo clássico. Por exemplo, as poses estatuescas do balé são ícones claros do corpo clássico.

\footnotetext{
*********A mais recente coleção de ensaios de Nancy Mairs (1996) aborda o tema da de/eficiência (dis/ability).

******* Quando eu estava finalizando este manuscrito, foi lançado o livro de Rosemarie Garland Thomson, Extraordinary Bodies (1997) (Corpos Extraordinários), que aborda as imagens da deficiência. No capítulo introdutório, intitulado Politicizing Bodily Difference (Politizando a diferença corporal) ela fornece importantes informaçóes sobre o histórico (background) da $A D A$.

********Pode-se argumentar que não é uma mera coincidência histórica, mas sim uma reação muito violenta e específica contra grupos proativos que trabalham com o tema da deficiência. Para mais discussóes sobre como a sociedade molda os corpos segundo suas próprias imagens ideais, ver Bordo (1993) e Martin (1994).
} 
Assim também o são os bailarinos em algumas companhias modernas e contemporâneas que privilegiam o corpo abstrato, como os corpos despreocupadamente elegantes que atuam hoje na Merce Cunningham Dance Company. A dança, como é baseada num corpo vivo, está carregada da ansiedade cultural de que o corpo grotesco irá brotar (inesperadamente) por entre a imagem do corpo clássico, estilhaçando a ilusão de desenvoltura e graça através da presença perturbadora de uma experiência carnal - respiração pesada, suor, erros técnicos, lesões físicas, e até a evidência da mortalidade ou da idade de um bailarino.

Em um palco de dança, a força perturbadora representada pelo mero pensamento de ver corpos deficientes, doentes ou morrendo pode ser avaliada pela tremenda controvérsia ao redor da resposta de Arlene Croce $(1994,1995)$ ao trabalho épico sobre doenças terminais de Bill T. Jones, Still/Here (Ainda/Aqui). Numa tentativa de assegurar seu lugar nos anais das famigeradas guerras culturais, Croce (uma crítica de dança do The New Yorker) afirmou que ela não poderia fazer a análise crítica de uma dança que contivesse imagens gravadas de pessoas morrendo. Em seu ensaio blasfemo que ataca a arte do oprimido de Discussing the Undiscussable (Discutindo o Indiscutível), Croce $(1994,1994)$ ataca "dançarinos com sobrepeso", "dançarino velhos", "dançarinos com pé torto", assim como "dançarinos com deformidades físicas que aparecem toda noite em papeis que demandam beleza de linhas" (p. 55). Injuriando qualquer arte politizada que salienta a identidade corporal do artista ("negros desrespeitados, mulheres que sofreram abuso ou homossexuais desprovidos de direitos"), ela lamenta a morte do teatro como ela conhece. "No teatro, a pessoa escolhe o que quer ser. O elenco do Still/Here - as pessoas doentes que Jones contratou - não tem outra escolha além de ser doentes" (p. 55). A implicação aqui é que os únicos corpos que valem ser vistos são aqueles que significam escolha, um código para corpos que estão conformes com padrões idealizados de saúde, capacidade física e beleza. Neste tipo peculiar de lógica, os corpos marcados pela diferença (alguém escolhe raça, altura ou sexualidade?) não tem escolha - seus desvios ao mesmo tempo os definem e os marginalizam.

Eu acredito que a bronca de Croce teve seu início nos primórdios de 1989, quando Jones levou Demian Acquavella aos palcos - um membro da companhia tão devastado pela AIDS que mal podia ficar de pé no palco durante a apresentação de D-Man in the Waters. Esta coreografia foi dedicada a Acquavella (a epígrafe do programa é um trecho de Jenny Holzer, "Em um sonho você viu uma maneira de sobreviver e ficou cheio de alegria"), e Jones dava um apoio a Acquavella para ele fazer os movimentos de braços do que era para ter sido seu solo na coreografia. Apesar de o espetáculo ter sido aclamado como uma síntese brilhante de uma dança expressiva e virtuosa com uma partitura musical formalmente estruturada (Octeto em Mi para cordas de Mendelssohn), a crítica tinha reações controversas a este último gesto, sugerindo que se tratava de manipulação emocional ou autopromoção flagrante. Por exemplo, no final de uma matéria que seria elogiosa, Márcia Siegel (1989) escreveu: "Eu acho que aqui Jones confundiu realismo com autobiografia ... Com a participação de Acquavella, D-Man in the Waters sacrifica o comentário agudo pela catarse imediata". Como a birra crítica de Croce, os comentários de Siegel refletem um medo profundo de que o impacto emocional do corpo real (leia-se grotesco) vá ficar no caminho de uma apreciação mais intelectual da composição coreográfica de Jones. Como atesta este artigo, no entanto, acredito que a perturbação do real que a deficiência simboliza pode fazer com que pensemos de uma maneira diferente sobre as relações entre a representação e a verdadeira história dos corpos.

Eu assisti a esta apresentação no Joyce Theater em Nova lorque e lembro de ter ficado espantada com as diferenças atordoantes entre a dança suave, rápida e poderosa de Arthur Aviles (que recebeu o prêmio Bessie por seu trabalho neste espetáculo) e os gestos espasmódicos da parte superior do corpo de Acquavella (ele estava sofrendo de mielopatia, uma doença 
relacionada à AIDS que afeta o sistema nervoso). Ao assistir a seu corpo debilitado entre todos os corpos fulgurosos, saudáveis e virtuosos de seus colegas de companhia, eu me dei conta do quão profundamente deficiência e corpo grotesco estão ao mesmo tempo incrustados (e reprimidos) na dança. Olhando para os meus comentários no jornal sobre esta apresentação, notei que, depois de ter descrito as coreografias, eu escrevi: "Meu Deus, deve ser intenso dançar nesta companhia agora. Arte e vida." Assim como a versão de 1989 de D-Man in the Waters e Still/ Here, muitas coreografias contemporâneas jogam evocativamente com a tensão entre arte e vida - entre o corpo clássico e o grotesco ${ }^{* * * * * * *}$.

Uma vez que a dança no ocidente tem privilegiado corpos capazes, contidos e virtuosos, não é de se admirar que várias companhias de dança, com bailarinos deficientes e não deficientes, trabalhem duro para salientar o corpo clássico, enfatizando que os corpos de todos os seus bailarinos são rigorosamente treinados e estão tecnicamente sob controle. Esta integração de corpos deficientes em uma forma de arte que constituiu o corpo estatuesco (e esculturado) como ícone nos dá uma oportunidade maravilhosa de investigar o diálogo cultural entre o corpo clássico e o grotesco. Este diálogo se dá cada vez que corpos vivos aparecem no palco, claro, mas o fato de que isso é conscientemente articulado na publicidade, na reação do público e na crítica a respeito de grupos de dança integrados nos dá a oportunidade de perceber a rede de discursos contraditórios sobre o corpo dentro da dança.

O posicionamento do corpo deficiente dentro do discurso clássico de técnica e virtuosidade não deixa de ser afetado pelo gênero. $O$ gênero está inscrito de uma forma muito diferente em um corpo deficiente, e tem surgido muito material escrito concernente à maneira pela qual a deficiência pode masculinizar o homem (cujas identidades vinculadas ao gênero são frequentemente contingentes em demonstrações de autonomia, independência e força) assim como dessexualizar as mulheres. Contudo, o poder social que outorgamos às representações de corpos masculinos parece dar aos bailarinos deficientes homens (com poucas exceções) mais liberdade para mostrar seus corpos na dança. Minhas próprias observações e pesquisa sugerem que bailarinos deficientes homens podem evocar o corpo virtuoso e tecnicamente incrível (até mesmo sem pernas, como veremos), e, no entanto, eles ainda são capazes de desconstruir o corpo clássico, permitindo que a plateia veja seus corpos sob uma luz diferente. Como nós vimos no caso de Verdi-Fletcher e o Cleveland Ballet Dancing Wheels, as mulheres deficientes estão mais aptas a se prenderem à imagem de uma bailarina como sendo graciosa, elegante, forte e bonita. A seguir, eu vou olhar para vários grupos de dança cujo trabalho tem, de diferentes maneiras, revolucionado as noções de capacidade física na dança contemporânea. Tanto a Candoco (com o corpo deficiente masculino) e a Light Motion (com o corpo deficiente feminino) estabeleceram novas imagens de virtuosidade física e excelência de técnica - destruindo as pressuposições de que a dança virtuosa requer quatro membros que funcionem. Além disso, existe uma forma de dança em desenvolvimento com habilidades mistas, vinda da comunidade do Contact Improvisation, que adota um ponto de vista estético completamente diferente. A Candoco e a Light Motion redefinem a virtuosidade na dança, e o Contact Improvisation redefine o corpo na dança, abrindo a possibilidade de podermos olhar para o corpo dançante como um corpo em processo, um corpo tornando-se. Esta atenção ao fluxo em constante mudança de corpos e a infindável abertura da improvisação dá um novo foco ao olhar da plateia, nos ajudando a ver o corpo deficiente em seus próprios termos.

\footnotetext{
********Certamente, a extraordinária influência do Butô japonês na dança contemporânea americana se encontra na brilhante síntese entre corpos grotescos e clássicos. Através do uso de repetições, mudanças dramáticas na velocidade e nos níveis, bem como de vocalizações, o Butô revela o grotesco dentro do clássico e vice-versa. Como atesto na Introdução do livro Choregraphing Difference... (1997), na qual descrevo as últimas produções de Les Ballets C. de la B., esta é uma outra companhia cujos trabalhos transitam nesse continuum.
} 
A Candoco é uma companhia britânica de dança profissional que evoluiu da conversa entre Celeste Dandeker, ex-bailarina do London Contemporary Dance Theatre que ficou paralítica em função de uma lesão na coluna ocorrida durante um espetáculo, e Adam Benjamin, um dançarino que estava lecionando em Londres no Heaffey Centre, um centro recreacional para portadores e não portadores de deficiência ligado à ASPIRE (The Association for Spinal Injury Research, Rehabilitation, and Reintegration - Associação de reabilitação, reintegração e pesquisa em lesão de coluna). Em 1991, estes dois dançarinos começaram uma pequena turma de dança para bailarinos deficientes e não deficientes. Desde então, Benjamin e Dandeker fundaram uma companhia profissional com oito bailarinos e um extenso repertório de trabalhos dos coreógrafos experimentais mais interessantes da Inglaterra atualmente. A Candoco tem recebido vários prêmios em reconhecimento pelo seu trabalho, e a companhia foi selecionada para a série na televisão (Dance for Camera, da BBC).

Ao apresentar a filosofia da companhia à imprensa e ao público em geral, Adam Benjamin escolheu redefinir o termo integração. Em seu texto sobre os objetivos e a história da companhia, In Search of Integrity (Em Busca da Integridade), com estilo de manifesto, Benjamin (1993) escreve:

De tempos em tempos, vê-se o uso, ou o mau uso, desta palavra, integração, para descrever um grupo ou atividade que se abriu para incluir pessoas com deficiências. Para integrar um grupo de pessoas dessa maneira, é claro, implica-se uma norma na qual elas precisam se encaixar. Se, entretanto, você estiver usando a palavra integrar, do latim integratus, é obrigado a reconhecer que elas já são uma parte integral do todo, mesmo que você ainda não tenha encontrado um espaço para elas. (p. 44).

Apesar de a filosofia de Benjamin ser bastante radical em muitas frentes e apesar de a Candoco ter encomendado algumas coreografias muito interessantes que não apenas "acomodam" os dançarinos deficientes, mas, como poderemos ver, remodelam percepções culturais sobre uma fisicalidade "capaz", Benjamin ainda está comprometido com elementos clássicos de virtuosidade técnica. Para Benjamin (1993), a verdadeira integração significa insistir em altos padrões de excelência profissional a fim de criar trabalhos coreográficos interessantes para todos os dançarinos da companhia. Ele critica companhias

(...) onde dançarinos altamente treinados 'dançam em círculos' ao redor dos deficientes com quem partilham o palco, e não muito mais que isso, onde não houve muito esforço por parte do coreógrafo para capacitar o artista a se comunicar... Pior ainda são as coreografias em que os dançarinos treinados, com corpos não deficientes perambulam inconsequentemente, como se envergonhados por suas próprias condições físicas, usadas, pelo contrário, simplesmente para passar por entre os perplexos ocupantes de cadeiras de roda. (p. 44)

Reconhecendo a necessidade de criar o estilo de dança próprio que acomodará diferentes possibilidades físicas, os dançarinos da Candoco estão constantemente tentando novas manei- 
ras de usar o momentum, trabalhando em uma variedade de níveis, inclusive o chão, e coordenando pernas e rodas. Em uma crítica da temporada de outono de $1992 \mathrm{em}$ Londres, Chris de Marigny (1993) relata o próprio espanto com o trabalho da Candoco.

\begin{abstract}
Deveras, todos os dançarinos atuam com habilidade incrível. Isto é possível pelas extraordinárias soluções coreográficas que foram inventadas para permitir que estas pessoas, com as mais diferentes deficiências, criem as imagens mais lindas e surpreendentes. Novos conceitos de cair, debruçar-se e sustentar foram criados para fazer um trabalho ao mesmo tempo lírico e por vezes energético. (p. 30)
\end{abstract}

Lendo a discussão da imprensa sobre as primeiras apresentações da Candoco, não há dúvida de que esta companhia ampliou as noções das pessoas sobre o que é possível em companhias de dança de bailarinos com capacidade física mista. Contudo, por contar com um dançarino deficiente muito excepcional para derrubar as preconcepções do público sobre deficiência, a Candoco às vezes recria (sem querer) novas distinções entre os corpos clássicos (virtuosos) e os grotescos (passivos) na companhia.

Victoria Marks foi uma das primeiras coreógrafas a trabalhar com a Candoco (ela fez as primeiras aulas da companhia no Heaffey Center e criou The Edge of the Forest para eles em 1991), e sua coreografia foi a vitrine para o filme sobre dança da BBC de Margaret Williams, Outside In. Um filme lírico que entrelaça paisagens surreais pastorais com ritmos suspensos e urbanos do tango e a batida da world music, Outside In começa com um beijo que se expande e passa de um membro da companhia ao outro. A câmera demora em cada rosto, registrando o deleite de cada um em receber o beijo e também deixando o espectador ver como cada beijo é transformado a caminho da próxima pessoa. Um corte transporta a ação para um espaço cavernoso onde uma única cadeira de rodas vazia roda para o foco da câmera. Então a companhia rapidamente se separa e se reúne inúmeras vezes, criando o desenho de um labirinto de giz no chão. Esta é a primeira vez que o espectador vê os corpos inteiros e os estilos individuais de locomoção. Um dos mais surpreendentes é David Toole, com sua habilidade de girar através do espaço por meio de seus braços. Toole é um dos três bailarinos deficientes, mas ele é o único que com facilidade sobe em sua cadeira e sai dela. Toole não tem pernas. Em vez delas, ele conta com seus braços fortes para caminhar. Ironicamente, o fato de ele não ter a parte inferior de seu corpo lhe dá uma enorme liberdade de movimento. Sua presença é maravilhosamente quixotesca, e ele consegue praticamente pular de sua cadeira para o chão e de volta para cima dela em um piscar de olhos.

As habilidades de Toole como dançarino são altamente notáveis. Na verdade, sua dança é frequentemente alvo de vastas discussões em artigos e críticas sobre a Candoco. Adjetivos como incrível, inacreditável, estupendo salpicam livremente as descrições de sua dança. Por exemplo, um artigo do Ballet International, que faz a crítica do desempenho de várias companhias de dança britânicas durante a temporada de primavera de 1993, coloca a dança de Toole como foco central num artigo sobre a Candoco.

David Toole é um homem sem pernas que tem mais graciosidade e presença do que a maioria dos bailarinos jamais poderão sonhar em ter... Toole comanda o palco com um atletismo que beira o milagroso. (MARIGNY, 1993, p. 29) 
Esta linguagem de espanto reflete tanto o despertar entusiasta (sim, um homem deficiente pode andar com estilo!) quanto os traços de um freak-show voyeurístico (veja os feitos extraordinários do homem sem pernas!). A dança virtuosa de David Toole tem um preço - um preço físico. Recentemente, sob recomendação de seus médicos, Toole teve de parar de dançar. A sua extraordinária mobilidade é predicado da sua habilidade de carregar o peso de seu corpo inteiro em seus braços, o que lhe permite caminhar, correr, ou mesmo saltitar por todo o palco. Infelizmente, estas façanhas surpreendentes estão na verdade destruindo seus braços e ombros. Em função de seu status de dançarino virtuoso, contudo, Toole acharia difícil continuar atuando de uma maneira que não machucasse seu corpo (numa cadeira de rodas, por exemplo) ${ }^{* * * * * * *}$.

Um dos únicos artigos a abordar conscientemente a questão do olhar que usamos para assistir a um corpo como o de Toole foi curiosamente escrito por um crítico francês. Na revista Les Saisons de la Danse, edição de maio de 1994, Delphine Goater escreveu uma crítica curta de um show da Candoco em que ela arrisca fazer algumas perguntas desconfortáveis. Uma das primeiras coisas a me surpreender neste texto foi como a língua francesa ainda tem que acomodar a terminologia politicamente correta. Por exemplo, os dançarinos não deficientes são descritos como valide (que significa tanto válido como saudável). Depois, havia também a franqueza descarada com que Goater (1994) perguntou:

Alguém olha para o dançarino deficiente com pena, com admiração pela sua performance, ou como se ele fosse um artista apenas parcialmente inteiro? Não há um pouco de voyeurismo ou curiosidade aí? (p. 23)

As perguntas de Goater(1994) remetem ao perigo de olhar para este tipo de trabalho, à possibilidade de o corpo grotesco poder reafirmar-se como espetáculo, mas, então, ela rapidamente assegura seus leitores de que a performance de Toole é linda e deslumbrante.

Apesar de a mídia cinematográfica ser notória por seu olhar voyeurístico e pela tendência de fazer de tudo um espetáculo, e apesar de Toole ser um dos artistas mais destacados em Outside In, a combinação de cinematografia habilidosa e coreografia inventiva neste filme realmente leva nossos olhares para longe da visão extraordinária do corpo de Toole e para perto dos contextos interativos de sua dança. Mesmo quando se movendo sozinho, Toole está sempre dialogando com a movimentação de outra pessoa. Por exemplo, na segunda cena, depois de o grupo ter deixado o espaço, uma mulher permanece, pisando nos desenhos circulares criados pelas cadeiras de roda. Nós a vemos escolhendo um desenho interessante e improvisando com ele - um sacode-sacode aqui, outro lá. O fato de ela estar reproduzindo o padrão das cadeiras em seu corpo só fica completamente claro quando a câmera passa para Toole, que se aproxima executando uma tarefa parecida, que é a de traduzir as pegadas atrevidas do diagrama de passos, de Arthur Murray, em seu próprio corpo. A princípio, ele parece hesitar, deixando seus dedos deslizarem sobre os contornos pretos de uma sola de sapato. Mas então ele olha diretamente para a câmera e, levantando os ombros com um olhar determinado, ele se lança

\footnotetext{
*********Eu estou em divida com Jodi Falk, por ela ter me emprestado uma cópia do programa de TV britânico Here and Now (Aqui e agora), que contém um trecho sobre a aposentadoria de Toole. Na sua apresentação de Falk na Conferência do CORD (Congress on Research in Dance) em 1996, ela cita uma matéria sobre a Candoco de junho de 1996, que lamentava a partida de Toole, referindo-se ao resto da Companhia como "um grupo de dançarinos competente mas pouco notável".
} 
numa vistosa interpretação de tango. Depois de uma breve sequência de tango com toda a companhia, este solo chega a um dueto extenso com Sue Smith. A negociação usual de desejo em um tango é substituída aqui pela negociação respeitosa das mudanças de níveis. Desde o momento em que Smith sobe a bordo da cadeira de Toole até a última tomada deles saindo em rolamentos, a coreografia nega a ideologia implícita de ficar de pé, colocando a maior parte do movimento no chão. A cinematografia se repete, filmando-os no nível do olho (o que quer dizer no nível do chão). A habilidade da câmera de mudar de pontos de vista sem interrupção nos dá uma das mais engenhosas maneiras de quebrar (literalmente espedaçar) um olhar preconceituoso - aquele que sempre ignora as pessoas que não estão (de pé) na frente de seu nariz.

Enquanto a mobilidade da câmera em si permite novas e maravilhosas maneiras de ver os dançarinos, a mídia cinematográfica tende a reforçar imagens do corpo clássico ao fazer todos parecerem tão bem. Em Outside In, nós perdemos o impacto experimental da respiração, o som dos baques e quedas, o suor e a evidência física (cabelo fora do lugar, figurino desalinhado, etc.) desta dança muito sinestésica. Isto é mais evidente nas bailarinas, que parecem todas muito belas ao longo do vídeo. Então, dada a coreografia inovadora da cena anterior, fiquei surpresa com o caráter mundano e passivo da coreografia das cadeiras de rodas na parte seguinte, em que vemos os dançarinos sem deficiência ajudarem, rolarem e inclinarem as cadeiras, enquanto nelas Johnathan French e Celeste Dandeker fazem uma série de movimentos decorativos com os braços. A notória diferença entre a dança de Toole e a de Dandeker e French me impressionou, de alguma forma reforçando uma noção de que estar em uma cadeira de rodas é fisicamente menos interessante do que estar fora dela. Ironicamente, apesar de ser um homem e uma muIher, os dois dançarinos ficam definidos dentro do contexto do filme como muito mais passivos e femininos do que Toole. Embora Outside In liberte nossas noções de diferença física nos dando a oportunidade de ver corpos diferentes em ação, não rompeu suficientemente os códigos iconográficos em que a cadeira de rodas significa de/eficiência. Para ver como uma cadeira pode se tornar efetivamente parte do corpo dançante, devemos nos voltar ao trabalho de outra companhia, a Light Motion.

Charlene Curtiss era uma ginasta competitiva e uma entusiasta desportiva, quando aos 17 anos lesionou a coluna em um aparelho de barras paralelas assimétricas com defeito. No início, Curtiss resistiu ao estigma da cadeira de rodas, lutando com bengalas e braçadeiras. Entretanto, durante um campeonato nacional de cadeiras de rodas, ela mudou de ideia ao ver as incríveis possibilidades de movimentos disponíveis aos usuários de cadeiras de rodas. Em 1988, Curtiss fundou a Light Motion para "desenvolver a expressão artística de artistas deficientes e não deficientes trabalhando juntos para expandir a consciência da comunidade sobre questões de deficiência através das artes". Hoje Curtiss leciona e atua como dançarina em cadeira de rodas, usando as habilidades que ela adquiriu em eventos esportivos, tais como o slalom de cadeira de rodas, para criar excitantes novas maneiras de se mover através do espaço sobre rodas. Em agosto de 1993, Curtiss atuou, como artista convidada, no programa de gala do Cleveland Ballet Dancing Wheels, em seu dueto em parceria com Joanne Petroff intitulado The Laughing Game.

O Laughing Game inicia com dois dançarinos (um sobre rodas e outro sobre pernas) se aproximando e circulando um em volta do outro, e algumas vezes descansando em momentos de imobilidade complementar. Depois de um ou dois minutos, o tempo da música acelera e se torna muito mais vivo, ao que os bailarinos respondem na mesma moeda com sua movimentação. É espelhando a complexidade do ritmo da música que a coreografia para rodas começa a ser realmente interessante. Usando técnicas que ela aprendeu no slalom de cadeiras de rodas, Curtiss executa rápidas mudanças percussivas de direção, trocando com destreza de lado a lado. 
Ela também consegue girar como uma patinadora no gelo e parar bruscamente. Às vezes a coreografia de cadeira de rodas é visualmente mais interessante que a coreografia para pernas, mas na maior parte do tempo a parceria dos dançarinos complementa a ênfase física ou rítmica do outro. Por exemplo, Quando Curtiss começa a tomar um momentum em um determinado ponto, Petroff precisa realmente jogar seu peso para contrabalançar, evitando que sua parceira voe para fora do palco. Para mim foi visualmente refrescante e sinestésico ver Petroff usar toda sua fisicalidade de uma maneira tão funcional e não decorativa. Assim também foi o momento em que Curtiss rodou sobre uma Petroff de bruços. Mais tarde em The Laughing Game, os dançarinos ecoam o diálogo percussivo da música. Nessa cena, Curtiss faz sua cadeira andar pomposamente no contratempo dos passos e lançamentos de pernas de Petroff, mostrando-nos como a cadeira, conhecida pelo seu deslizar suave e sua capacidade de girar, também pode afirmar um ritmo próprio dela.

A dança de Curtiss é diferente de qualquer outra dança em cadeira de rodas que eu já tenha visto. Curtis trabalha de maneira colaborativa na coreografia, por isso ela tem sido capaz de compor conscientemente a representação de de/eficiência que é apresentada na dança. Para Curtiss,

(...) é importante que a pessoa sem deficiência não tente levar a pessoa deficiente nos movimentos. Você está dançando com alguém com deficiência, mas você tem que dançar com eles como eles são ... Você não me puxa em uma pirueta. Você me deixa puxá-la eu mesma. (Wheelchair..., 1993)

O que me parece interessante na sua atuação é como Curtiss afirma a cadeira de rodas como uma extensão de seu corpo. A cadeira se torna mais do que um recurso que facilita andar daqui para lá. Em vez disso, é parte dela, expressa sua personalidade e estilo de movimento. Esta troca é concretizada por causa da maneira com que Curtiss integra sua cadeira com a musicalidade de seu próprio corpo. Cadeiras de rodas, mesmo deslizando no solo, podem parecer muito estáticas e sem corpo, mas Curtiss usa a dela para combinar com os ritmos da parte superior de seu corpo, subindo entusiasmadamente em uma demi-roda para entrar no tempo da música. O fato de que Curtiss consegue criar um groove e um beebop com sua cadeira de rodas revisa a significância cultural da cadeira, expandindo sua legibilidade de sinal dos inválidos para um signo de personificação.

Apesar de companhias como a Candoco e a Light Motion estarem produzindo trabalhos que não escondem a deficiência, mas sim usam a diferença da habilidade física para conceber coreografias novas e inventivas, eu sinto que muito do seu trabalho ainda bebe em um ethos que restaura o corpo clássico dentro do deficiente. Apesar de incorporadas de maneiras diferentes, concepções culturais de graça, velocidade, força, agilidade e controle estruturam, contudo, a estética destas companhias. Assim, mesmo que todos os grupos que integram dançarinos deficientes e não deficientes tenham certamente ampliado a imaginação cultural sobre quem pode se tornar um dançarino, no meu ponto de vista eles não desconstruíram plenamente o privilégio da capacidade física dentro da dança. O trabalho cultural mais radical está atualmente ocorrendo dentro da comunidade do Contact Improvisation.

Dar uma descrição mais coerente do Contact Improvisation é complicado, pois esta forma tem se expandido exponencialmente através do tempo e viajou por muitos países e comunidades de dança. Apesar de ter sido desenvolvido nos anos 70, o Contact Improvisation tem raízes 
claras nas revoluções sociais e estéticas dos anos 60. O Contato abrange ao mesmo tempo o ethos casual, individualista e improvisatório da dança social, além da experimentação com dos movimentos pedestres e de tarefas rotineiras, preferidos pelo primeiros grupos de dança pós-modernos, tais como o Judson Church Dance Theater. Resistindo tanto ao corpo idealizado do balé, como ao corpo dramaticamente expressivo da dança moderna, o Contato procura criar o que Cynthia Novack (1990) chama de "um corpo que responde", baseado na troca física de peso ${ }^{* * * * * * *}$. Diferentemente de muitos gêneros de dança que salientam a necessidade de controle do movimento (com admoestações para parar, apertar e posicionar o corpo), o treinamento físico do Contato enfatiza a liberação do peso do corpo sobre o chão ou sobre o corpo do colega. No Contato, a experiência das sensações internas e do fluir do movimento entre dois corpos é mais importante que formas específicas ou posições formais. Os dançarinos aprendem a se mover com a consciência da comunicação física implícita na dança. Curt Siddall (citado Gamble, 1977), um antigo expoente do Contact Improvisation, descreve a forma como uma combinação de forças sinestésicas:

(...) o Contact Improvisation é uma forma de movimento de natureza improvisacional, envolvendo os dois corpos em contato. Impulsos, peso e momentum são comunicados através um ponto de contato físico que continuamente atravessa ou circunda os corpos dos dançarinos. (p. 36)

Mas corpos humanos, especialmente os que estão em contato físico um com o outro, são difíceis de serem vistos apenas nos termos de contrabalanço físico, peso e momentum. Interpretando um corpo como literal e metafórico, o Contato expõe o caráter interconectado das preocupações sociais, físicas e estéticas. Hoje, uma parte importante do Contact Improvisation é o desejo de permitir as metáforas físicas e as narrativas de amor, poder e competição para evoluir do que era a ênfase original no trabalho de uma interação física. Assistindo ao Contato pela primeira vez, as pessoas geralmente se perguntam se isso é dança profissional ou se é uma forma recreacional ou terapêutica. As linhas formais da dança muito clássica se foram. As abordagens tradicionais para as coreografias e as convenções do palco tradicional se foram. Em seu lugar, está a forma de movimento improvisacional, baseada na comunicação expressiva envolvida quando duas pessoas começam a compartilhar seu peso e apoio físico. Em vez de privilegiar um tipo ideal de corpo ou estilo de movimento, o Contact Improvisation privilegia uma vontade de se arriscar física e emocionalmente, produzindo uma certa desorientação psíquica em que as categorias aparentemente estáveis de capaz e incapaz são desalojadas.

É o Contact Improvisation que fornece o fundamento físico para um dueto entre Charlene Curtiss e Bruce Curtiss, um bailarino de São Francisco. Bruce Curtiss é um bailarino tetraplégico envolvido com o Contact Improvisation desde a década de 1980, quando ele começou a dançar com o veterano do contato Alan Ptashek. Bruce é professor de dança e tornou-se bem conhecido por atuar frequentemente como facilitador de workshops como o DanceAbility, que ocorre anualmente em Eugene, estado de Oregon. Produzido pela Joint Forces e dirigido por Alito Alessi, este evento tornou-se modelo para workshops como esse em todo o mundo. Como Steve Paxton (1992) concisamente colocou em seu artigo sobre o Wokshop DanceAbility de 1991, Bruce "é aceito como performer, convidado como professor. Já ouvimos falar de um bailarino-professor tetraplégico antes? Seguramente não" (p. 13).

******** Para referências sobre a Judson Dance Theater ver o trabalho de Sally Bannes (1980, 1983) sobre esta 
O dueto de improvisação de Charlene e Bruce começa no estilo clássico do Contato, com os dois bailarinos circulando um em volta do outro, sentindo a energia e as preferências de movimentação um do outro. (Sair ou não da cadeira de rodas, eis a questão.) Inicialmente, eles mantêm as suas cinesferas próprias, mas então Charlene estende um braço em direção a Bruce, que responde deitando sua cabeça no ombro dela. Após esse breve momento compartiIhando o peso, eles circulam e rodopiam em volta um do outro até que Charlene fica rodando bem atrás de Bruce, que inclina todo seu corpo para trás, pendendo sua cadeira para o colo de Charlene. Este momento provoca uma troca física de peso da frente para trás e vice-versa que os leva gradualmente até o chão passando por alguns níveis. Bruce, cuja experiência em dança é predominantemente baseada no Contato, parece estar mais disposto a se colocar em posições estranhas, ou a botar seu peso em cima de sua parceira. Por outro lado, Charlene parece querer manter sua relação visual e sutilmente muda seu corpo de modo a manter um contato olho-a-olho (mais do que corpo-a-corpo). Depois de vários minutos no solo, Charlene retorna à mobilidade mais facilitada de sua cadeira, em um determinado ponto dando voltas e voltas ao redor de Bruce, jogando-o dentro de um turbilhão no solo. A negociação física de níveis espaciais e momentum que é necessária quando Charlene está na cadeira e Bruce está no solo fornece uma das interações mais interessantes de seu dueto. E também nos dá um exemplo de dois bailarinos com deficiências bem diferentes rompendo ainda mais com o clássico binário deficiente/não deficiente. Esta visão (lugar) de dois bailarinos deficientes trabalhando juntos é uma visão radical e se faz possível, creio eu, pelas (re)figurações estéticas e físicas disponíveis no Contact Improvisation.

Como observei antes, o Contact Improvisation foca na relação física de um corpo com o outro, dando ênfase às sensações sinestésicas e à física de peso e momentum mais do que à figura visual da forma corporal dentro do espaço do palco. Dessa forma, o Contato estimula uma atenção à experiência momentânea dos bailarinos em vez de postular uma necessidade de se enquadrar em uma imagem idealizada. Embora tenha desenvolvido, ao longo de seus 25 anos de história, uma elite profissional de renomados professores e bailarinos virtuosísticos, o Contact Improvisation ainda é uma forma de dança essencialmente casual, popular, que conta com seus praticantes para espalhar a palavra e a dança. Não há nenhuma instituição centralizada que licencie, administre, dê certificados ou supervisione a disseminação desta forma de dança. Pelo contrário, há uma variedade de saudáveis redes de trabalho estabelecidas, incluindo jams, oficinas, conferências e o periódico bianual Contact Quarterly. Esta estrutura aberta permitiu que o Contato crescesse em muitas e diferentes direções. Durante o período em que fiquei envolvida em dançar e ensinar esta forma, eu vi o Contact Improvisation mudar de curso inúmeras vezes, porém a mudança mais dramática ocorreu no final dos anos 80 , quando, no ápice de um período de virtuosidade incrível (no qual todo mundo parecia estar voando em alta velocidade sobre os ombros uns dos outros), houve uma mudança repentina de interesse para a exploração da troca física entre pessoas com tipos diferentes de capacidades físicas - uma reforma radical que resultou em uma prioridade bem diferente no dançar. Seria fútil tentar explicar todos os motivos desta mudança notável. Acredito que ela venha de uma variedade de fatores históricos, incluindo o momento cultural de maior consciência da deficiência nas artes, assim como o desejo no Contact Improvisation de negar o conhecido, o hábito fácil, o caminho já bem traçado. Embora tenha ressurgido em comunidades diferentes e com um senso de oportunidade novo, este foco levou o Contato a dar toda uma volta e retornar às suas raízes democráticas.

A de/eficiência na dança profissional tem sido frequentemente um código para um tipo de deficiência - qual seja, a paralisia do corpo inferior. Contudo, em encontros de Contact Improvisation como o workshop anual DanceAbility e o Breitenbush Jam, os bailarinos têm uma gama bem mais ampla de deficiências, incluindo a deficiência visual, a surdez e problemas neuro- 
lógicos como a paralisia cerebral. Paxton (1992) cria uma bela metáfora para esta mistura de talentos quando escreve:

Um grupo que inclui diversas deficiências é como as Nações Unidas dos sentidos. As instruções devem ser traduzidas em particularidades apropriadas para os sobre pernas, rodas, bengalas, e devem ser traduzidas em sinais para os surdos. As apresentações devem ser verbalizadas para aqueles que não podem ver, o que em si gera uma habilidade de tradução, já que o inglês não é uma língua flexível nos termos do corpo. (p. 16)

Minha primeira experiência com este trabalho ocorreu na primavera de 1992, quando eu e minha filha de (então) 5 meses fomos à jam anual de dança Breitenbush. Esta jam, que ocorre em um retiro de águas termais em Oregon, não é feita especificamente para portadores de deficiência como o são as oficinas do DanceAbility, então considero o fato de que pessoas com vários estilos de movimento e capacidades físicas participem do evento como bailarinos uma prova do sucesso da verdadeira integração dentro da comunidade do Contato. No início da jam, enquanto nos apresentávamos para o grupo, Bruce Curtiss, que estava de facilitador deste trabalho em questão, sugeriu que, em sequência, cada pessoa no círculo tivesse a oportunidade de falar sobre suas necessidades físicas e seus desejos para aquela semana de dança ininterrupta. Bruce falava partindo do ponto de vista de que várias pessoas têm necessidades especiais, não apenas aquelas que são mais obviamente deficientes. Essa consciência da deficiência como um continuum, e não uma situação de e/ou, permitiu que todos os presentes pudessem falar sem o estigma de caracterizar a si mesmos como deficientes ou não, apenas com base na capacidade física. Por exemplo, a minha necessidade especial era de alguma ajuda para cuidar de minha filha para que eu pudesse colocar alguma dança no corpo. Em um determinado momento mais tarde, Emery Blackwell, um bailarino com paralisia cerebral, veio me socorrer, amarrando-a em seu colo e saindo para dar uma volta com ela em sua cadeira de rodas motorizada.

Desde aquela jam, Eu tive muitas outras experiências dançando com pessoas (inclusive crianças) que são fisicamente deficientes. Contudo, não seria sincero eu dizer que minha primeira vez dançando com Emery ou Bruce foi igual a fazer Contact Improvisation com outro qualquer. Não foi - um fato que tinha mais a ver com as minhas percepções do que com as fisicalidades deles. Inicialmente, eu tinha medo de esmagar o corpo de Emery. Depois de vê-lo dançar com outros que tinham mais familiaridade com ele, reconheci que ele estava apto para uma dança bem arrojada e gradualmente comecei a confiar mais em nossa comunicação física para conseguir desligar o alarme interno que ficava lembrando dentro de minha cabeça que eu estava dançando com alguém com uma deficiência (isto é, um corpo frágil). Contudo, minha capacidade de mudar para uma relação diferente de dança com Emery foi menos um resultado da aceitação aberta de qualquer corpo pelo Contato do que de seu treinamento (tanto físico como psicológico), o qual gerou uma vontade de me sentir intensamente desajeitada e desconfortável. A questão não era se eu estava dançando com um corpo clássico ou não, mas se eu poderia soltar as expectativas clássicas do meu próprio corpo. Dançar com Emery foi desorientador para mim porque tive de abandonar as minhas expectativas. Felizmente, o treino para a desorientação que é fundamental para o Contato me ajudou a recriar meu corpo em resposta ao dele. À medida que eu desloco o eixo das minhas experiências como bailarina para minha posição como crítica, a pergunta que se mantém para mim é: o Contact Improvisation reorganiza as nossas prioridades de visão desta mesma maneira? 
Emery Blackwell e Alito Alessi vivem em Eugene, Oregon, uma cidade especialmente desenhada para ser acessível para cadeiras de rodas. Blackwell foi presidente da OIL (Oregonians for Independent Living - cidadãos de Oregon por uma vida independente) até que deixou 0 cargo apara dedicar-se à dança. Alessi, um veterano do Contato que teve várias experiências com deficiências físicas (inclusive um acidente que lhe rompeu os tendões de um tornozelo), tem coordenado os workshops da DanceAbility em Eugene nos últimos cinco anos. Além da participação neste tipo de fórum, Blackwell e Alessi têm dançado juntos nos últimos 8 anos, criando trabalhos coreográficos, como seu dueto Wheels of Fortune, e duetos de improvisação, como uma performance que vi na Breitenbush Jam.

O dueto de Blackwell e Alessi começa com Alessi rolando no solo e Blackwell rodando perifericamente em volta do espaço da performance em uma cadeira de rodas. Os olhos deles estão se focando, criando uma conexão que dá aos dois movimentos de rolamento uma certa sincronia de propósito. Depois de vários círculos em volta do espaço, Blackwell para sua cadeira, todo o tempo olhando para seu parceiro. A intensidade do olhar se reflete nas constantes vibrações de impulsos de movimento em sua cabeça e mãos, e esta observação o aproxima dele. Blackwell oferece a Alessi uma mão e inicia-se uma série de trocas de peso que começa com Alessi gentilmente se inclinando para longe do centro de peso de Blackwell e termina com ele andando de cabeça para baixo no colo de Blackwell. Mais tarde, Blackwell em parte desliza, em parte se retorce para fora de sua cadeira e caminha sobre seus joelhos até Alessi. De braços abertos, os dois homens fazem movimentos espelhados até que um impulso errático leva Alessi e Blackwell ao chão. Eles estão rolando simultaneamente um atrás do outro pelo solo quando, de repente, a frequência de movimentos de Blackwell acelera, e seu corpo literalmente começa a quicar com a energia em excesso. Alessi responde na mesma moeda e os dois momentaneamente entram em uma turbulenta, mas amistosa forma de luta com cambalhotas e tudo. Depois de um tempo, eles ficam exaustos e começam a se aquietar, rolando lado a lado para fora do espaço da performance.

Anteriormente eu argumentei que, justamente porque o corpo deficiente é culturalmente codificado como grotesco, muitos grupos de dança integrados enfatizam as dimensões clássicas dos movimentos do corpo deficiente - a graciosidade de uma cadeira de rodas deslizando, a força e a agilidade da parte superior do corpo das pessoas, etc. O que me chama a atenção na dança de Blackwell neste dueto é o fato de que seu movimento inicialmente evoca imagens do grotesco e, então, guia nossos olhos, através do espetáculo de seu corpo, para dentro da experiência de sua fisicalidade particular. Paxton (1992) uma vez escreveu uma descrição detalhada da dança de Blackwell.

Emery disse que, para conseguir fazer seu braço se erguer acima de sua cabeça, são necessários 20 segundos de técnica de imagem. Impulsos de extensão e contração são enviados frequente e imprevisivelmente para seus músculos, e ele deve de alguma forma selecionar os impulsos certos de maneira consciente, ou produzir para si mesmo uma imagem de movimento da qualidade certa para conseguir que o braço responda da maneira que ele quer. Nós observadores podemos ficar encantados com o que ele está fazendo com sua mente. Mais objetivamente, podemos ver que, conforme ele tenta, ele excita seus impulsos motores, e estes impulsos aleatórios acontecem com mais vigor. A dança dele tem um Ardil-22 embutido. E nós sentimos este dilema e percebemos que ele joga contra o próprio sistema 
nervoso e ganha, com esforço e um tipo de mecanismo em sua mente que nós não deficientes não tivemos que aprender a construir. Sua destreza com estes dois fatores nos permite percebê-los sutilmente em nossas mentes. (p. 14)

Steve Paxton é considerado o pai do Contact Improvisation por muitas pessoas, visto que foi seu workshop e sua performance na Oberlin College em 1972 que deram a primeira fagulha de vida às experimentações que mais tarde tornaram-se esta forma de dança. Dado o engajamento de Paxton no Contato por vinte e cinco anos, faz sentido ele ser um perito para analisar a dança de Blackwell. De fato, a descrição de Paxton do movimento de Blackwell capta a maneira como o Contact Improvisation se foca no tornar-se - o processo improvisacional de evolução que nunca chega a um fim. O Contato pode representar o corpo deficiente exatamente porque não tenta recriar os enquadramentos estéticos de um corpo clássico ou de um contexto de dança tradicional. Por exemplo, o proscênio do palco da maioria das apresentações de dança cria um enquadramento visual que tende a focar em demonstrações de virtuosidade, usos do espaço teatral, assim como a apresentação de linhas visuais (como um arabesque, por exemplo). $O$ Contato, por outro lado, nega este enquadramento ao priorizar o processo em andamento - 0 tornar-se - da dança ${ }^{* * * * * * *}$. Colocando de maneira mais simples, a questão aqui não é o que os bailarinos podem fazer, mas como eles fazem. Concentrando-se assim no tornar-se de sua dança, o dueto de Blackwell e Alessi nega uma representação estática da de/eficiência, envolvendo o público como testemunha das negociações de sua experiência física que estão em andamento. É importante se dar conta de que a dança de Alessi, ao ser responsiva sem, contudo, ser preciosista, ajuda a fornecer o contexto para este tipo de engajamento testemunhal também. Em seu dueto, Alessi e Blackwell estão engajados em um diálogo de movimento improvisacional no qual os dois parceiros estão se movendo e sendo movidos um pelo outro. Acho este dueto interessante porque demonstra o potencial extraordinário em juntar duas pessoas com condições físicas bem distintas para compartilhar no movimento um do outro. Neste espaço entre a dança de salão, a luta e a intimidade física, encontra-se uma forma de dança cuja estética aberta e a atenção à flexibilidade de identidades de movimento podem (in)formar e ser (in)formadas pelo movimento de qualquer corpo.

Nós obviamente chegamos bem longe da descrição de Taglioni feita por Gautier, com a qual comecei este texto. Ao longo da trajetória de mapeamento da rota coreográfica da bailarina clássica romântica até o bailarino de Contato deficiente - do corpo clássico ao grotesco -, parece que deixamos algumas mulheres no caminho. À exceção de Charlene Curtiss (que em geral tem trabalhos coreográficos, mais do que improvisacionais), eu conheço poucas mulheres deficientes dançando no gênero do Contact Improvisation. Por que não há mais mulheres portadoras de deficiência ativas em ensinar e apresentar este tipo de trabalho? É uma pergunta difícil, e pode ser que haja mulheres por aí que eu não conheça, no entanto acredito que a resposta tenha algo a ver com as mulheres com princípio de dupla tipicidade (em especial as mulheres deficientes) quando elas expõem seus corpos sem as armadilhas protetoras da atitude, dos figurinos, dos movimentos ou enquadramentos do corpo clássico.

Mary Russo (1986) começa seu ensaio Female Grotesques: Carnival and Theory (Grotescos femininos: Carnaval e Teoria) com uma expressão que remete a sua infância: "She's making a spectacle out of herself ${ }^{* * * * * * * \prime \prime}$ (p. 213). Mary explica o que esta frase realmente quer dizer:

\footnotetext{
********Essa é uma das razóes pelas quais o Contato raramente trabalha em palcos tradicionais, com proscênio. Geralmente, as apresentações de Contact Improvisation se realizam em espaços alternativos, às vezes em círculos. ********N. T.: Literalmente traduzido, seria: ela está fazendo dela mesma um espetáculo; esta expressão idiomática quer dizer que a mulher em questão está se expondo ao ridículo.
} 


\begin{abstract}
Para uma mulher, fazer de si mesma um espetáculo tinha mais a ver com um tipo de inadvertência e perda de limites: as proprietárias de coxas grandes, velhas e cheias de celulite na beira da praia, de bochechas com excesso de ruge, de um esganiço que escapasse na risada, ou de uma alça de sutiã que caísse - especialmente aquela alça solta e encardida - eram todas de uma vez flagradas pelo destino e pela repreensão (p. 213).
\end{abstract}

Temos aqui duas noções contraditórias de espetáculo. "Fazer dela mesma um espetáculo" não é, ironicamente, convidar o olhar voyeurístico (o qual na dança em geral é reservado para representações do corpo clássico), pois este olhar desejoso é dependente de uma separação física e espacial do si e do outro. O corpo feminino grotesco, pelo contrário, confronta e desafia este olhar. A perda de limites descrita por Russo como socialmente repreensível provoca um medo de contágio, o medo de que a presença visível das "coxas grandes, velhas e cheias de celulite" de outra pessoa vá amolecer as coxas de quem as vê.

Os entrelaços da representação e da experiência corporal são tão interessantes quanto contraditórios aqui, posto que o corpo grotesco (que Bakhtin vê encarnado nas antigas manequins de argila de velhas corocas grávidas rindo) tende muito mais a ser definido como um corpo feminino (poroso, encharcado, sexual) que excede seus limites socialmente definidos (um corpo fora [do estado] de controle). Acrescente deficiência a esta mistura discursiva, e os cruzamentos são especialmente interessantes fascinantes e complexos. Visto que mulheres deficientes são duplamente definidas por seus corpos transgressores, culpadas por seus excessos físicos (peitos caídos, quadris grandes) ou falhas. A advertência ouvida na infância de Russo para não "fazer de si mesma um espetáculo" é uma injunção que a maioria das portadoras de deficiência ainda sentem com força irrestrita.

\title{
Referências
}

ADAIR, Christy. Women and Dance: Sylphs and Sirens. Nova lorque: New York University Press, 1992.

ALBRIGHT, Ann Cooper. Coreographing Difference: The Body and Identity in Contemporary Dance. Wesleyan University Press, 1997. 1980.

BANNES, Sally. Terpsichore in Sneakers. Post-Modern Dance. Boston: Houghton Mifflin,

BANNES, Sally. Democracy's Body: Judson Dance Theater 1962-1964. Michigan: UMI Research Press, 1983.

BENJAMIN, Adam. In Search of Integrity. Dance Theater Journal, v. 10, n. 4. Outono, 1993.

BORDO, Susan. Unbearable Weight: Feminism, Western Culture, and the Body. Berkeley: University of California Press, 1993.

CROCE, Arlene. Discussing the Undiscussable. The New Yorker, Nova lorque, 26 dez. 1994. 
CROCE, Arlene. Discussing the Undiscussable. The New Yorker, Nova lorque, 22 jan. 1995.

FALK, Jodi. Questioning the Dancing Body. CORD Conference Proceedings, 1996.

GAMBLE, John. On Contact Improvisation. The Painted Bride Quarterly, v. 4, n. 1, Primavera, 1977.

GOATER, Delphine. Eł pourtant ils dansent. Les saisons de la danse, n. 256, maio, 1994.

GALLER, Roberta. The Myth of the Perfect Body. In VENCE, Carol (Ed.). Pleasure and Danger: Exploring Female Sexuality. Boston: Routledge and Kegan Paul, 1984.

GORDON, Suzanne. Off Balance: The Real World Of Ballet. Nova lorque: Pantheon, 1983.

KIRKLAND, Gelsey; LAWRENCE, Greg. Dancing on my Grave: An Autobiography. Nova lorque: Doubleday, 1986.

GUEST, Ivor (Ed.). Gautier on Dance. Londres: Dance Books, 1986.

HILLYER, Barbara. Feminism and Disability. Norman: University of Oklahoma Press, 1993.

KING, Ynestra. The Other Body: Reflection on Difference, Disability, and Identity Politics. Ms.3, n. 5, março/abril, 1993.

MAIRS, Nancy. On Being a Cripple. Plaintext. Tucson: University of Arizona Press, 1986, p. 9-10.

MAIRS, Nancy. Waist-High in the World: A Life among the Nondisabled. Boston: Beacon Press, 1996.

MAIRS, Nancy. Carnal Acts. Boston: Beacon Press, 1996.

MARIGNY, Chris de. A Little World of Its Own. Ballet International, v. 16, n. 3, junho, 1993.

MARTIN, Emily. Flexible Bodies: The Role of Immunity in American Culture from teh Days of Pólio to the Age of AIDS. Boston: Beacon Press, 1994.

NOVACK, Cynthia. Sharing the Dance: Contact Improvisation and American Culture. Madison: University of Wisconsin Press, 1990.

PAXTON, Steve. 3 Days. Contact Querterly, v. 17, n. 1. Inverno, 1992.

RUSSO, Mary. Female Grotesques: Carnival and Theory. In LAURETIS, Teresa de (Ed.). Feminist Studies/ Critical Studies. Bloomington: Indiana University Press, 1986.

SIEGEL, Márcia. Survival by Drowning. New York Press. Nova lorque, 17 abr., 1989.

SOLOMONS, Gus Jr. Seven Men. Village Voice. Nova lorque. 17 março. 1992.

THOMSON, Rosemarie Garland. Extraordinary Bodies. New York: Columbia University Press, 1997.

VINCENT, L. M. Competing with the Sylph: Dancers and the Pursuit of the Ideal Body Form. Kansas City: Andrews and McMeel, 1979.

Wheelchair Dancer Teaches Moves to Disabled Performers. Tri-City Herald. Seattle, 1 jun., 1993. 
WRIGHT, Steve. DisabledGirl, 6, Beams as Dancers Wheel trhough Ballet. Cleveland Ballet Dancing Wheels, 1993.

ULE-GROHOL, Melinda. Dance Movements in Time: Cleveland, 1995. 